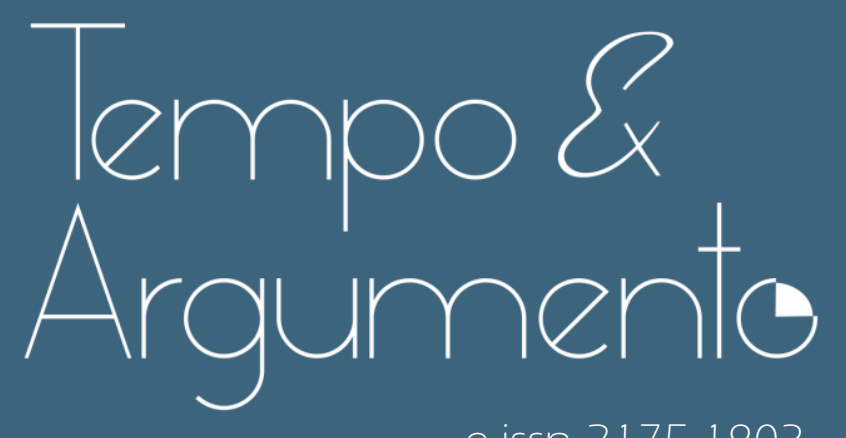

e-issn 2175-1803

\begin{abstract}
A verdade da História no jornalismo e o lugar do jornalismo na história: apontamentos críticos de uma relação guiada pela noção de acontecimento
\end{abstract}

- André Bonsanto

Doutor em Comunicação pela Universidade Federal Fluminense (UFF) Professor colaborador e bolsista de Pós-doutorado (PNPD/CAPES) junto ao Programa de

PósGraduação em Ciências Sociais e Humanas (PPGCISH) da Universidade do Estado do Rio Grande do Norte (UERN).

Mossoró, RN - BRASIL

lattes.cnpq.br/5025469064512821

andrebonsanto@gmail.com

(D) orcid.org/0000-0001-8406-4009

Para citar este artigo:

BONSANTO, André. A verdade da História no jornalismo e o lugar do jornalismo na história: apontamentos críticos de uma relação guiada pela noção de acontecimento. Tempo e Argumento, Florianópolis, v. 12, n. 29, e0208, jan./abr. 2020.

do) http://dx.doi.org/10.5965/2175180312292020e0208

Recebido: 04/10/2019

Aprovado: 06/03/2020 


\title{
A verdade da História no jornalismo e o lugar do jornalismo na história: apontamentos críticos de uma relação guiada pela noção de acontecimento
}

\begin{abstract}
Resumo
Este artigo procura problematizar uma possível aproximação entre a História e o jornalismo ao analisar como uma ideia particular de "verdade" se entrelaça à constituição de suas identidades e discursos. Desta forma, propomos realizar uma discussão teórico-metodológica que nos permita: 1) historicizar o conceito de "verdade" da/na História e como este se encontra circunscrito à própria ideia de verdade proferida pelo jornalismo enquanto instituição; 2) perceber como o jornalismo, ao se apropriar discursivamente desta "verdade", procura circunscrever o seu lugar na história; 3) problematizar, pela noção de "acontecimento", um ponto de interseção que se daria entre o jornalismo, a memória e a história, relação capaz de dotar as verdades do jornalismo de algumas características que the são próprias. Queremos discutir, com isso, de que forma o jornalismo procura se fazer histórico, relacionando a "verdade" de seus relatos e a autoridade de suas práticas à constante reapresentação dos acontecimentos no tempo.
\end{abstract}

Palavras-chave: História. Memória. Jornalismo. Verdade. Acontecimento.

\section{The truth of History in journalism and the place of journalism in history: critical notes of a relation guided by the notion of event}

\begin{abstract}
This article seeks to problematize a possible approach between History and journalism, analyzing how a particular idea of "truth" is intertwined with the constitution of their identities and discourses. In this way, we propose to carry out a theoretical-methodological discussion that allows us to: 1) historicize the concept of "truth" of/in History and how it is circumscribed to the very idea of truth uttered by journalism as an institution; 2) understand how journalism, by appropriating this "truth" discursively, seeks to circumscribe its place in history, 3) problematize, by the notion of "event", a point of intersection that would occur between journalism, memory and history, a relationship capable of endowing the truths of journalism with some particular characteristics. We want to argue with that how journalism seeks to make itself historic, relating the "truth" of its reports and the authority of its practices to the constant re-presentation of events over time.
\end{abstract}

Keywords: History. Memory. Journalism. Truth. Event. 
Quando penso sobre a atividade do jornalista, sempre acabo por compará-lo com a do historiador. Acho que são atividades semelhantes em algum sentido. O jornalista é uma espécie de historiador "a quente". Um dos melhores resultados que o jornalista pode ter é elaborar um relato que possa ser utilizado mais tarde, com proveito, pelo historiador. (Otávio Frias Filho)'.

Sendo um registro taquigráfico da História, o jornalismo sofre necessariamente o primeiro impacto dos fatos. Até por isso convém que ele seja reexaminado periodicamente, a fim de aferir se sua atividade está sendo capaz de projetar alguma luz para além da efervescência dos acontecimentos, se seus critérios estão sendo os melhores para franquear uma leitura ao mesmo tempo fidedigna, reveladora e útil, se não da realidade, ao menos da sua superfície diária. (Folha de S. Paulo) ${ }^{2}$.

Hoje em dia, mais do que em qualquer período de nossos tempos, os conceitos de história e de jornalismo mantêm uma total afinidade. Convivem tão intimamente que tentar separá-los resultará em grave erro de avaliação histórica ou em imperdoável falha de compreensão do fenômeno jornalístico. (Roberto Marinho) $)^{3}$.

O jornalista investiga os fatos, pouco a pouco, e vai montando um quebra-cabeça. O retrato final estará ainda incompleto, à espera da História, mas terá de ser já, necessariamente, uma silhueta com contornos visíveis. (O Globo) 4

Apesar de proferidas em contextos diversos, as epígrafes acima evidenciam como o chamado jornalismo profissional no Brasil, representado por dois de seus principais jornais na figura dos seus então dirigentes, enxerga uma relação que pretendemos problematizar aqui de forma comprometida: a do jornalismo com a História. Nosso objetivo é direcionar um olhar para a história a fim de perceber como o jornalismo procura, a partir dela, legitimar a própria ideia de verdade produzida por seus relatos. A verdade da história diz respeito, portanto, à própria constituição da autoridade do jornalismo, uma vez que para ele é fundamental não apenas inserir seus discursos na história, mas se dizer reconhecidamente capacitado a produzir tais discursos, legitimando determinadas verdades dos/sobre os acontecimentos no tempo. Desta forma, partimos do pressuposto de que é pela noção de "acontecimento" que poderemos pensar um ponto de interseção para tensionar estas relações, que se dariam entre o jornalismo, a memória e a história. Isso porque o que está em

\footnotetext{
${ }^{1}$ Frias Filho (2003, p. 375).

2 PROJETO... (1997, sem paginação).

${ }^{3}$ Marinho, apud Ribeiro (2005).

${ }^{4}$ PRINCÍPIOS... (2011).
} 
A verdade da História no jornalismo e o lugar do jornalismo na história: apontamentos críticos de uma relação guiada pela noção de acontecimento

André Bonsanto

jogo aqui não seria apenas a mera inscrição destes acontecimentos enquanto relatos noticiosos, mas principalmente a forma como eles são dilatados, re(a)presentados e utilizados nos mais diferentes presentes da enunciação. Ao competir com uma série de outros atores, discursos e instituições para legitimar as (suas) "verdades" sobre os acontecimentos, o que o jornalismo faz é se apropriar de sua própria produção discursiva para conduzir uma narrativa que se pretende histórica, pela forma como é acionada e ressignificada a partir das conjunturas mais diversas.

Nossa preocupação aqui consistirá, portanto, em delinear um percurso do reconhecimento do jornalismo enquanto instituição, nas suas imbricadas aproximações com a memória e a história. Essa problemática é fruto de uma pesquisa maior na qual procuramos diagnosticar o que definimos como uma "história da verdade" do/no jornalismo, com o intuito de perceber como se legitimou no Brasil uma espécie de ideal moderno desta instituição, balizado sob preceitos que supostamente configurariam a prática profissional do "verdadeiro" jornalismo: aquele que em tese produz um relato objetivo, isento, baseado na busca de uma verdade factual dos acontecimentos e por isso digno de confiança e credibilidade. (BONSANTO, 2018)

É por isso que, quando falamos de jornalismo e história, falamos também de memória e autoridade, já que acontecimentos só podem legitimar-se enquanto tais pela forma como são inscritos, dilatados, rememorados e, acima de tudo, apropriados em presentes bem particulares. Vamos seguir as pistas de Roberto Marinho e Otávio Frias Filho, colocadas nas epígrafes deste artigo. Afinal, que História é esta que completaria o trabalho do jornalismo? Seria o jornalista nada mais do que um historiador "a quente"? Que "registro taquigráfico" é este que ele conseguiria absorver da superfície diária dos acontecimentos? Se recebe o primeiro impacto dos fatos, poderia o jornalismo ir além de retratar uma mera silhueta do que reporta? Ao se dizer capaz de relatar "historicamente" o mundo que o cerca, o que o jornalismo intenta, conforme veremos, é se fazer histórico, no sentido de portar-se como autorizado e legítimo a construir narrativamente tais acontecimentos. Vejamos como se constitui esta relação nem sempre tão aparente. 


\section{A verdade da História no jornalismo: uma aproximação possível?}

Como acreditavam os gregos em seus mitos? Como é possível acreditar "pela metade" ou até mesmo em coisas contraditórias? Da mesma forma que as crianças acreditam em Papai Noel, mesmo sabendo que os presentes são entregues, na verdade, pelos seus próprios pais. Essa reflexão, feita pelo historiador Paul Veyne (2014), nos parece interessante para começarmos a pontuar o problema da verdade e suas implicações na historiografia. De acordo com ele, a "pluralidade das modalidades de crença" se constitui historicamente, sendo criada e modificada culturalmente pela forma como é imaginada no tempo. Desta forma, os homens "fazem" suas verdades assim como fazem a história que os constitui.

Os gregos seriam assim "menos verdadeiros" ou mais ingênuos do que nós por terem acreditado na mera palavra dada, nos mitos, por terem atribuído valor de verdade à tradição? Não, se pensarmos que a verdade é um construto social e mutável e que, portanto, cada época, realidade e conjuntura configuram uma forma específica de enxergar estas relações entre crença, verdade e história. Pensando desta forma, Veyne (2014, p. 15) acredita que a história, como a conhecemos hoje, em seu sentido "moderno", teria em comum com a prática dos gregos apenas o nome. Isso não significa que esta fosse imperfeita ou que necessitasse de progressos. Enquanto gênero narrativo, - e merecedora de crédito frente a seus contemporâneos, - estaria tão acabada como o próprio jornalismo, "ao qual se assemelha muito", afirmava. Àquele momento um historiador nem sequer citava suas fontes e a verdade histórica se dava quase como uma "vulgata". Os autores recopiavam-se uns aos outros e legitimavam-se como uma tradição, "eles presumiam que o predecessor dizia a verdade [...] a tradição existia e era a verdade, e acabou-se." (VEYNE, 2014, p. 23). Os historiadores não citavam suas fontes, como em notas de rodapé, por exemplo, pois não as julgavam estritamente necessárias. Era o próprio historiador com o seu relato que se transformava em fonte e documento, corrigindo-se e sendo alimentado constantemente pela narrativa, visto que ele mesmo se considerava uma "autoridade em potência". 
A verdade da História no jornalismo e o lugar do jornalismo na história: apontamentos críticos de uma relação guiada pela noção de acontecimento

André Bonsanto

Poderíamos assim, ainda segundo Veyne (2014, p. 26), "nos divertir" com a analogia entre os historiadores antigos e a deontologia jornalística, já que, de acordo com ele, um jornalista é julgado muito mais pela crítica interna em relação ao seu erro/parcialidade no trato da informação do que pelo respeito para com as fontes. Neste sentido, um "bom historiador" antigo não deveria "acolher cegamente" todas as tradições que the chegassem, mas saber verificar a informação como fazem os repórteres. Os historiadores antigos verificavam a informação "por sua conta”, sem deixar tal preocupação para o leitor. Prática que os diferenciava dos historiadores modernos, que propunham uma interpretação dos fatos, evidenciando suas fontes e fornecendo aos leitores os meios para verificá-las, possibilitando, quando possível, outras vias de interpretação.

Esta prática se daria, portanto, pela própria relação de reconhecimento para com seu público. Crença e verdade eram baseadas acima de tudo na relação com o outro, na credibilidade e na confiança. O mito, pensado desta forma, não soaria nem verdadeiro nem falso, mas como uma informação que precisaria de uma fonte que o legitimasse, aquela que seria a de seu próprio autor e da instituição que o representava. Mas, se na antiguidade os relatos eram sempre direcionados a um público "tão heterogêneo quanto o de um jornal”, podendo os historiadores se manter no direito do sigilo das fontes, com a profissionalização da história, os historiadores deixaram de escrever apenas para simples leitores, voltando-se também para seus pares junto à academia, para outros historiadores. O mito passou assim a sofrer com a concorrência dos "especialistas da verdade", historiadores profissionais que se dotavam de autoridade para interpretar e explicar os acontecimentos do mundo. Autoridade esta que não se limitava mais ao simples poder de dizer, na vulgata da tradição, mas por métodos e procedimentos que garantiriam aura de cientificidade a uma prática que então se profissionalizava (VEYNE, 2014).

Apesar de percebermos certa ironia do historiador em sua analogia com o jornalismo, não nos interessa indagar a que tipo de atividade ele estava de fato se referindo. Conforme vimos nas epígrafes, o jornalismo estaria aqui relacionado a uma narrativa baseada em fatos que procura descrever, da forma mais fidedigna possível, uma dada realidade. Seus relatos deveriam dar ao menos uma 
A verdade da História no jornalismo e o lugar do jornalismo na história: apontamentos críticos de uma relação guiada pela noção de acontecimento

André Bonsanto

"silhueta com contornos visíveis" desta realidade, a ser utilizada posteriormente em proveito da História. Assim, o jornalismo é encarado, ao menos para estes jornais, como uma atividade que em tese iria além do mero relato mítico e sem pretensão de veracidade. Devemos pensar, portanto, que quando este jornalismo se refere à História ele também está se referindo, ao que parece, a uma disciplina dotada de cientificidade, ou, ao menos, de critérios que poderiam validar e ampliar sua narrativa, feita muitas vezes no calor dos acontecimentos.

Estaremos desta forma tratando de uma História em maiúscula, institucionalizada, que, científica ou não, se configurou enquanto tal somente a partir de meados do século XIX. Não nos compete problematizar aqui como ela se legitimou a partir de tal estatuto, a partir de árduos embates epistemológicos protagonizados pela filosofia da história e pela historiografia como um todo. ${ }^{5} \mathrm{~A}$ questão é pensar a História como uma prática discursiva que, na tentativa de emancipar-se das narrativas míticas e dos relatos literários, se pautou progressivamente em torno de uma busca particular pela verdade. Tal busca só seria possível, acreditavam os "modernos" historiadores, com a padronização de suas práticas, dotando-as de um "método com suas regras, seus ritos, modos particulares de entronização e de reconhecimento." (DOSSE, 2003, p. 37).

Com historiadores "modernos", nos referimos aos seguidores de um paradigma que se constituiu com a chamada escola "metódica", surgida oficialmente na França e potencializada a partir da clássica obra/manual de Charles-Victor Langlois e Charles Seignobos: "Introdução aos estudos históricos" (1898). Uma obra que pretendia colocar os historiadores no panteão dos "cientistas puros", distanciando-os definitivamente da literatura pela implementação de métodos que minassem a subjetividade dos relatos. O "bom" historiador profissional seria assim reconhecido pela utilização de critérios científicos que colocavam em primeiro plano a "reivindicação da objetividade",

\footnotetext{
Para mais informação sobre a constituição da disciplina histórica e suas reflexões epistemológicas ao longo do tempo, consultar as obras: CARR, Edward Hallet. Que é história? Rio de Janeiro: Paz e Terra, 1982; DOSSE, François. A história. Bauru, SP: EDUSC, 2003.; LE GOFF, Jacques. História e memória. Campinas, SP: Editora Unicamp, 2003 e TOSH, John. A busca da história: objetivos, métodos e as tendências no estudo da história moderna. Petrópolis, RJ: vozes, 2011.
} 
A verdade da História no jornalismo e o lugar do jornalismo na história: apontamentos críticos de uma relação guiada pela noção de acontecimento

alcançando a verdade a partir de uma obsessão crítica por suas fontes, em detrimento da qualidade retórica e estética dos textos. (DOSSE, 2003) ${ }^{6}$.

A história, como uma "ciência positiva", deveria pautar-se sobretudo pela imparcialidade. A verdade só seria alcançada por um trabalho criterioso de análise das fontes. O historiador deveria apenas questioná-las e delas retirar o que elas teriam a dizer. Era o documento - e os fatos nele contidos - quem falava e garantia a legitimidade do trabalho historiográfico. Bastava apenas estabelecer estes fatos, garantir a autenticidade de que eles "realmente aconteceram", para que cessasse o trabalho do historiador. Mas, de acordo com François Dosse (2003), isso não significava mera ingenuidade por parte dos metódicos. Por mais que eles tivessem consciência da potencial subjetividade do historiador, sua capacidade estaria justamente em controlar as intenções individuais em seu trabalho. Uma escolha deliberada para frear supostos desvios de uma prática que queria se fazer reconhecida cientificamente.

O culto aos fatos por esta historiografia que se pretende moderna e mais profissional pode ser - salvo os devidos anacronismos e particularidades relacionado à ideia de um jornalismo "moderno" que também intentou legitimarse institucionalmente como uma prática mais "verdadeira", pela forma como se isentava no relato objetivo dos acontecimentos. Estes discursos procuraram legitimar historicamente a prática de um "bom" jornalismo, pautado sobretudo pelos atributos da independência, da imparcialidade e do apartidarismo. Jornalismo era assim relato de fatos, isentos e separados da opinião. Relato em forma de notícias que, da forma mais objetiva possível, deveriam transparecer em um discurso "fiel" à realidade.

\footnotetext{
- Na verdade, já na antiguidade, desde a obra de Tucídides, em sua "História da guerra do Peloponeso" (meados do século V a.C.), é possível perceber este "culto ao verdadeiro" e a preocupação do historiador com a busca de métodos estritamente objetivos no relato dos fatos. De acordo com Dosse (2003, p. 21), Tucídides teria reduzido a operação historiográfica a uma "restituição do tempo presente", que se caracterizava por um "ocultamento do narrador, que se retira para deixar falar os fatos. No próprio nascimento do gênero histórico, encontra-se, portanto, essa ilusão de auto-ocultamento do sujeito histórico e de sua prática da escrita para melhor dar ao leitor a impressão de que os fatos falam por si mesmos. Pura transitividade, o empreendimento histórico parece anular-se no relato constitutivo de seu objeto."

Não vamos nos ater aqui a este processo da dita modernização do jornalismo profissional no Brasil. Para mais informação, consultar a já referida obra de Bonsanto (2018) e ALBUQUERQUE, Afonso. Aconteceu num carnaval: algumas observações sobre o mito de origem do jornalismo brasileiro moderno. Eco-Pós. v,11, n,2, p. 95-116, ago./dez, 2008; ALBUQUERQUE, Afonso. A modernização autoritária do jornalismo brasileiro. Alceu, v. 10 n. 20, p. 100-115, jan./jun. 2010.
} 
A verdade da História no jornalismo e o lugar do jornalismo na história: apontamentos críticos de uma relação guiada pela noção de acontecimento

André Bonsanto

Forçando esta relação não queremos de modo nenhum homogeneizar e/ou simplificar a prática historiográfica. Sabemos que esta noção de história, já em tese superada, foi aprimorada por diversas inquietações de ordem filosófica e epistemológica que ampliaram o leque de possibilidades interpretativas no campo da historiografia. Novas interrogações, métodos e objetos deram ao ofício do historiador outras formas de problematizar suas "verdades" e a maneira como eles constroem as narrativas sobre tais verdades, seus fatos e acontecimentos. ${ }^{8}$ Estamos procurando aqui pensar apenas a profissionalização de uma História enquanto prática discursiva, mesmo que não seja nosso foco problematizar seu processo de institucionalização. Isso para que, vale ressaltar mais uma vez, possamos perceber possíveis aproximações do próprio jornalismo com um tipo particular de escrita da história, conforme veremos a seguir. Aproximação que é feita, - ao menos discursivamente, - de forma deliberada pela própria instituição jornalística, com o intuito de se autolegitimar e dar respaldo à sua atividade.

O pesquisador Felipe Pontes (2009), por exemplo, conseguiu diagnosticar um paralelo entre o desenvolvimento de ambas as disciplinas, em uma análise sobre aquilo que definiu como uma “história epistemológica do jornalismo" em sua relação com a historiografia. Para ele, tanto o jornalismo quanto a História possuem características comuns, já que ambos têm como foco o relato de acontecimentos ancorados na realidade, relatados a partir de narrativas e pautados, sobretudo, pela pretensão à verdade. São, portanto, atividades "políticas" e "literárias". Políticas, pois incidem sobre as maneiras pelas quais o seu público enxerga e pensa o mundo. Literárias porque ligam esta percepção a formas específicas de contar suas estórias, narrativa e poeticamente falando (PONTES, 2009, p. 153).

\footnotetext{
8 Uma análise panorâmica sobre as diferentes escolas e correntes historiográficas ao longo do tempo, bem como a ampliação de suas abordagens teórico-metodológicas/epistemológicas, pode ser conferida nas obras: BURKE, Peter. A escola dos annales (1929-1989): a revolução francesa da historiografia. São Paulo: UNESP, 1997; DOSSE, François. A história. Bauru: EDUSC, 2003; LE GOFF, Jacques; NORA, Pierre (orgs.) História: novos problemas; novas abordagens; novos objetos. Rio de Janeiro: F. Alves, 1976; CARDOSO, Ciro Flamarion; VAINFAS, Ronaldo (orgs,). Domínios da história: ensaios de teoria e metodologia. Rio de Janeiro: Campus, 1997 e NOVAIS, Fernando A.; SILVA, Rogério F. da (orgs.). Nova história em perspectiva. 2 v. São Paulo: Cosac Naify, 2013.
} 
A verdade da História no jornalismo e o lugar do jornalismo na história: apontamentos críticos de uma relação guiada pela noção de acontecimento

André Bonsanto

Além disso, a homogeneização e consequente profissionalização de ambas as práticas teria se aprofundado, concomitantemente, ao longo do século XIX, com a forte influência dos métodos positivistas e a ascensão da objetividade. Tal influência fez com que a experiência "poética" fosse em tese gradativamente subtraída, na tentativa de alcançar a tão almejada verdade factual e angariar assim uma reconhecida legitimidade para as instituições que produziam estes discursos. Neste sentido, é possível notar de forma clara, ainda pensando a história epistemológica do jornalismo, que muito do que se discute como "teoria do jornalismo" é nada mais do que um retorno a temas já bastante debatidos na teoria da História. Ainda assim, por mais que estejamos tratando de suas aparentes semelhanças, não devemos cair em abstrações para definir o jornalismo como uma espécie de "história do presente" e/ou uma história meramente "simplificada" (PONTES, 2009).

Aqui podemos entrar em um ponto fundamental. Se realmente existe uma ancoragem factual que garante legitimidade aos relatos da história, como os acontecimentos podem ser interpretados sob perspectivas diferentes ao longo do tempo? Como seus autores selecionam estes fatos e os apresentam sob os mais diversos pontos de vista? É possível garantir uma verdade estritamente objetiva destes fatos, já que sucessivamente as novas gerações são obrigadas a reescrever constantemente sua história? Na esteira de Adam Schaff (1995), acreditamos que, para pensarmos o problema da verdade na história, é preciso não "absolutizar" o sentido do conhecimento objetivo, visto que este é sempre passível de interferências humanas e, portanto, nunca absoluto, mas um processo em transformação. Como um processo, introduz sempre um fator subjetivo. Mas subjetividade não seria aqui mera "ficção especulativa" apartada do objeto ou opiniões individuais, mas um papel ativo do sujeito que constrói este conhecimento. Desta forma, é fundamental que pensemos a subjetividade não como algo que seja apenas inerente ao indivíduo, mas que seja objetivo e também social. Afirmar isto é dizer que a verdade absoluta é relativa e a verdade total, parcial. Só porque proferimos juízos a respeito de determinado acontecimento, isso não significa dizer que ele seja de fato verdadeiro. A sequência de juízos que constituem este processo e seus diversos pontos de 
A verdade da História no jornalismo e o lugar do jornalismo na história: apontamentos críticos de uma relação guiada pela noção de acontecimento

André Bonsanto

vista inscritos historicamente é que ajudariam a compor um quadro, sempre mutável, da verdade. A verdade, portada ao devir, se daria assim de forma cumulativa, em um processo infinito rumo a uma verdade absoluta/total praticamente inalcançável, pois sempre superada por novas interpretações. (SCHAFF, 1995).

Não podemos, no entanto, nos contentar com generalizações relativistas. Se toda história é produto de seu tempo, passível a diferentes interpretações e inscrita nos jogos de poder, ela não deve ser deslocada, como acredita Schaff (1995), de suas pretensões de veracidade, já que, de acordo com ele, há uma função social inerente a todo trabalho do historiador. Assim, por mais que parciais, nem todas as histórias devem ser encaradas como necessariamente verdadeiras, já que estão circunscritas e condicionadas à uma realidade factual que precede a validação de sua legitimidade discursiva.

Esperamos da história uma objetividade "que the seja conveniente" (RICOEUR, 1968). Uma objetividade que, "exigida” pela própria história, demandaria certa qualidade subjetiva do historiador. O historiador precisaria, portanto, cumprir esta tarefa para além de sua própria subjetividade, mas condicionando-se a uma subjetividade que seria dos homens, da história. Isso porque esta mesma história irá posteriormente se dirigir a outros homens que, para apreender as suas verdades, precisariam também de uma subjetividade reflexiva. Constrói-se assim um itinerário que vai da "objetividade da história à subjetividade do historiador", chegando a uma outra, que seria a subjetividade filosófica, presente no ato da leitura e da interpretação. (RICOEUR, 1968, p. 24).

A história é analítica, procura compreender, explicar. Reconstituir um acontecimento é "fazer falar" os documentos que o historiador tem em mãos com base em suas inquietações, elevando aquilo que aconteceu à categoria de fato histórico. Antes disso, o documento nem sequer pode ser considerado em suas potencialidades. É preciso que a atividade historiadora o recomponha em categorias de análise, para elaborar assim um encadeamento de fatos que se sucedem, se ampliam e dilatam, pois confrontados sob diferentes perspectivas. Não há um passado total a ser "resgatado" pela história justamente porque a 
A verdade da História no jornalismo e o lugar do jornalismo na história: apontamentos críticos de uma relação guiada pela noção de acontecimento

André Bonsanto

subjetividade do historiador deve ser pensada como um "julgamento de importância" construído deliberadamente (RICOEUR, 1968)9.

Neste constante diálogo entre a "objetividade histórica" e a "subjetividade historiadora" a História permanece sempre aberta e em debate, colocando-a também na esfera da comunicação, mesmo que não se espere dela uma efetiva reciprocidade. Busca-se a verdade pois se espera dizer uma palavra válida a todos, não algo que apenas me agrade, que seja inventado, mas "aquilo que é". Ricoeur propõe assim uma "definição intersubjetiva da verdade", em que cada um "se explica", desenvolvendo sua percepção do mundo no embate com o outro: "não há senão uma via de superação, a comunicação. Não tenho senão um meio de sair de mim mesmo: é expatriar-me em outrem. A comunicação é uma estrutura do conhecimento verdadeiro." (RICOEUR, 1968, p. 55-56) ${ }^{10}$.

Este caráter "pluridimensional" da verdade historiciza o processo de sua busca. Uma busca que historicamente se pautou pela violência política e simbólica, baseada na concepção autoritária de uma verdade única e irrefutável. Tal desejo seria demasiadamente ambíguo, pois, segundo Ricoeur (1968), a suposta unidade do verdadeiro nada mais representa do que sua mentira primordial. Essa "mentira da verdade" surge, assim, quando o desejo de unificação coincide com o fenômeno da autoridade. "É através das paixões do poder que certos homens exercem uma função unificadora." (RICOEUR, 1968, p. 180) A saída, ainda de acordo com o filósofo, só se tornaria possível com o respeito à complexidade das ordens de verdade, com o reconhecimento do plural baseado no estabelecimento de hierarquias.

\footnotetext{
9 Além disso, há de se pensar que o historiador, vinculado à objetividade da história, transfere-se sempre para um "outro presente" que não o dele, imbuindo-se assim daquilo que Ricoeur define como uma espécie de "imaginação" histórica: "a época que estuda é tida por ele como o presente de referência, como o centro de perspectiva temporal: existe um futuro desse presente, que se faz da espera, da ignorância, das previsões, dos temores dos homens de então, e não daquilo que nós sabemos ter acontecido; existe também um passado desse mesmo presente, que é a memória dos homens de outrora, e não aquilo que nós próprios sabemos do passado deles." (RICOEUR, 1968, p. 31)

Em contrapartida, uma ideia de verdade imutável, aparentemente "neutra" e descompromissada, acaba por ocultar uma situação real na qual a história pode "tornar-se sempre uma espécie de álibi para a pesquisa da verdade; é sempre possível ocultar-nos atrás da história com o fito de nada afirmarmos por nossa própria conta." (RICOEUR, 1968, p. 53)
} 
A verdade da História no jornalismo e o lugar do jornalismo na história: apontamentos críticos de uma relação guiada pela noção de acontecimento

Uma verdade no plural não diz respeito, portanto, à ideia de que todas as histórias possam ser consideradas verdadeiras, nem que que elas sejam validadas por sua mera "utilidade" frente à determinadas necessidades. Ao estabelecermos critérios, estamos nada mais do que realizando uma seleção de fatos que, sob a premissa da objetividade histórica, possam ser considerados como tais. Neste sentido, são os fatos que possuem um caráter relativo, eles tornam-se históricos pela forma como o historiador os enxerga e os relaciona no tempo, inserindo-os contextualmente em uma cadeia acontecimental. Critérios de escolha operam em sua seleção e valoração porque é a subjetividade do historiador que transforma o fato social, objetivo, em uma realidade dotada de potencialidades enunciativas. (SCHAFF, 1995) $)^{11}$.

Mas esta seleção jamais é arbitrária, já que os fatos existem objetivamente. Eles não são mero produto e/ou invenções do historiador. Sua escolha é precedida, ao menos em tese, de um suporte teórico-metodológico que conduz a maneira como são estabelecidos e hierarquizados estes fatos. É por isso que, frisamos novamente, nem tudo pode ser considerado digno de se tornar histórico. Não podemos compactuar, por exemplo, com a tese do historiador Paul Veyne (1987) de que a história "não explica" nem "tem método" e de que sua prática estaria assim baseada apenas na estrutura de um "romance verdadeiro". De acordo com esta premissa, basta que um fato tenha "realmente acontecido" para angariar seu estatuto de legitimidade histórica. De resto, a história “é o que é" e se revela pela forma como é narrada, bastando ao historiador encadear estes fatos na organização de uma intriga. O acontecimento, como um "cruzamento de itinerários possíveis" nada mais seria do que um corte, dentre outros possíveis, que se opera na realidade.

\footnotetext{
11 Se pensarmos que existem diversas maneiras de encarar a história, de manusear as fontes e reportá-las enquanto acontecimento é porque estamos dando à verdade, também, um teor "objetivo relativo". Isso não significa afirmar que verdades parciais, fragmentárias, sejam erros, mas que elas "constituem verdades objetivas, se bem que incompletas. Se a história [...] nunca está definitivamente acabada, se está subordinada a constantes reinterpretações, daí resulta apenas ser ela um processo, e não uma imagem definitivamente acabada, não uma verdade absoluta. Desde o momento em que se toma o conhecimento histórico como processo e superação das verdades históricas - como verdades aditivas, cumulativas - compreende-se o porquê da constante reinterpretação da história, da variabilidade da imagem histórica: variabilidade que, longe de negar a objetividade da verdade histórica, pelo contrário, a confirma." (SCHAFF, 1995, p. 277).
} 
A verdade da História no jornalismo e o lugar do jornalismo na história: apontamentos críticos de uma relação guiada pela noção de acontecimento

Para Veyne (1987, p. 167), portanto, a história não poderia ser considerada uma ciência e sua forma de explicar seria apenas a de "fazer compreender", descrever como as coisas se passaram: "O que não conduz a qualquer coisa de substancialmente diferente do que faz, cada manhã ou cada tarde, o nosso jornal habitual."12 Teses como estas procuram apreender uma realidade em que tudo se resume à confecção do ato narrativo. Apesar de considerar possíveis particularidades em relação à busca da verdade de seus relatos, estes autores acreditam que um romance literário, o jornalismo ou a história não se diferenciam enquanto estrutura, já que procuram explicar a realidade narrativamente, representando-a em forma de texto. O resto nada mais seria do que pretensões de uma aparente cientificidade normativa, jamais alcançada na prática.

Mas estas leituras nos soam interessantes porque ajudam justamente a tensionar a relação que aqui problematizamos, uma vez que o jornalismo, ao delinear atributos como os da "imparcialidade" e da "objetividade" de seus relatos, aciona um ritual estratégico que acaba muitas vezes por blindar sua prática e atividade discursiva. São eles que garantem certo estatuto de veracidade a narrativas que se querem mais "verdadeiras" do que outras. Isso se

\footnotetext{
12 A tese da "meta-história" de Hayden White (1992, p. 11), em termos parecidos, também procura problematizar o trabalho histórico como uma "estrutura verbal na forma de um discurso narrativo em prosa". De acordo com ele, a história explicaria seus acontecimentos não a partir de conceitos e/ou métodos pré-estabelecidos, mas pela superfície de seus textos. A história seria assim um ato essencialmente "poético" e linguístico. Um modelo interpretativo que se daria a partir de "formalizações", que são escolhas muito mais estéticas e morais do que epistemológicas. O historiador põe em enredo sua história a partir de acontecimentos "já constituídos", escolhendo e hierarquizando os elementos que formarão esta narrativa. Além disso, estas narrativas seriam compostas por "trópicos" que orientariam as direções dos textos: seus "estilos" e "tons", presentes em todo ato discursivo. Trópicos seriam assim os desvios de sentido criados frente ao ato poético que entrariam em conflito com aquilo que em tese deveria ser o "verdadeiro" no sentido do discurso. Os tropos são a alma do discurso, evidenciando que estes podem, portanto, ser sempre expressos de modos diversos: "estamos diante do fato inelutável de que, mesmo na prova discursiva mais pura, textos que pretendem representar "as coisas como elas são", sem floreios retóricos nem imagens poéticas, sempre há uma falha de intenção; [...] toda mimese se apresenta deformada e pode, portanto, servir de ensejo para uma outra descrição do mesmo fenômeno, uma descrição que se pretenda mais realista, mais "fiel aos fatos". [...] Um discurso move-se "para cá e para lá" entre as codificações recebidas da experiência e a congérie de fenômenos que recusa incorporar-se em noções convencionalizadas de "realidade", "verdade", ou "possibilidade". Também se move "para frente e para trás" (como uma lançadeira?) entre os meios alternativos de codificar essa realidade, dos quais alguns podem ser fornecidos pelas tradições do discurso que prevalecem num dado âmbito de investigação e outros podem ser idioletos do autor, cuja autoridade este está procurando estabelecer. O discurso, numa palavra, é quintessencialmente um empreendimento mediador. (WHITE, 1994, p. 15-17).
} 
A verdade da História no jornalismo e o lugar do jornalismo na história: apontamentos críticos de uma relação guiada pela noção de acontecimento

André Bonsanto

dá, e precisa ser constantemente reforçado, porque o jornalismo, enquanto instituição, não está necessariamente imbuído de procedimentos estritamente teórico-metodológicos para orientar suas práticas, mas se constitui a partir de normativas mais genéricas, construídas discursivamente. O que ocorre também em virtude de sua profissão ser, primordialmente, mais uma atividade comercial do que epistemológica/intelectual, como a história.

Não queremos com isso dar à História um estatuto eminentemente científico, em contraponto ao trabalho do jornalismo. Também não queremos trabalhar com uma oposição binária entre o jornalismo e a história, a ponto de tentar perceber qual narrativa seria mais legítima e/ou verdadeira, como se a História, em maiúscula, fosse uma atividade "pura" e o jornalismo, mera narrativa, "meta-história". 13 John Nerone (2013), por exemplo, acredita que tanto a história quanto o jornalismo, por construírem seus discursos com base em narrativas que se pretendem verdadeiras, estariam representados por uma espécie de "disciplina indisciplinada", visto que precisariam constantemente legitimar-se enquanto tal a partir de lutas de significação simbólica. Ambas as disciplinas, de acordo com sua premissa, profissionalizaram-se historicamente por noções comuns de produção de conhecimento coletivo. Práticas constituídas a partir de seu policiamento normativo, na medida em que ambas se pautam pela disciplina

\footnotetext{
13 Não queremos também menosprezar como um todo as teses "narrativistas" da história. Elas poderão auxiliar-nos a situar de forma mais estrita a construção do acontecimento jornalístico, e voltaremos a elas adiante. Pensando além, é importante problematizarmos, como faz Rancière (2014), na "cientificidade" inerente ao próprio ato narrativo. De acordo com ele, os embates travados entre uma história-ciência e a história-narrativa devem ser colocados no interior da própria construção do acontecimento, sejam eles "reais" ou "fictícios", visto que estes se constituem pela forma como são nomeados pelo encadeamento da narrativa, frente àquilo que o autor vai definir como uma "poética do saber": um "estudo do conjunto dos procedimentos literários pelos quais um discurso se subtrai da literatura, dá a si mesmo um status de ciência e significa-o. A poética do saber se interessa pelas regras, segundo as quais um saber se escreve e se lê, constitui-se como um gênero de discurso específico. Ela procura definir o modo de verdade a que ele se destina, sem the estabelecer normas, validar ou invalidar sua pretensão científica." (RANCIĖRE, 2014, p. 12) A busca da verdade, segundo esta premissa, estaria baseada mais do que na mera "exatidão dos fatos", na "confiabilidade das fontes" e no "rigor das induções", mas por um outro tipo de "regime", produzido pela fissura entra a "objetividade narrativa" e a "certeza" do discurso: "O papel do historiador não é mais contar as revoluções, mas interpretá-las, relacionar os acontecimentos e os discursos que os fundam e explicam. E, é claro, o que funda os acontecimentos é sempre o não acontecimento; o que explica as palavras é o que não é mais palavra. [...] Ele relaciona o discurso sedutor à realidade não discursiva que nele se exprime e se traveste. O discurso do historiador é um discursomedida que relaciona as palavras da história à sua verdade. É isso que quer dizer explicitamente interpretação." (RANCIÈRE, 2014, p. 48-49).
} 
A verdade da História no jornalismo e o lugar do jornalismo na história: apontamentos críticos de uma relação guiada pela noção de acontecimento

André Bonsanto

como forma de assegurar sua autoridade, delimitando o que poderia ser digno de reconhecimento em seus respectivos locais de produção.

Apesar de considerar o jornalismo como uma disciplina estrita frente à produção do conhecimento, Nerone (2013) acredita que suas normativas foram criadas inicialmente com um "termo de conveniência" que, apenas com o tempo, acabaram por se instituir como normas. Normas que, segundo ele, não estariam ligadas a um valor epistemológico formal, mas por "atos de colonização" que atuariam com o intuito de diferenciar o "verdadeiro" jornalismo daquele feito por "bárbaros" ou amadores. A profissionalização do jornalismo, neste caso, atuaria como uma importante estratégia para proteger as organizações de notícia e sua instituição. Neste sentido, a disciplina jornalística e suas normas possuem um caráter muito mais sociológico do que intelectual, já que vem atuando historicamente como um processo de distinção para definir seu “outro", não constituindo com isso uma teoria do jornalismo propriamente dita. (Nerone, 2013, p. 15)

Partindo destas constatações acreditamos que seria arriscado reduzir a história às suas teses narrativistas, negligenciando-a de seus métodos. A disciplina histórica, enquanto uma forma de organização discursiva particular, difere da atividade jornalística, ainda que ambas se constituam pelo ato narrativo. Principalmente porque problematizar a história enquanto disciplina nos permite pensar aqui o próprio jornalismo. Nosso objetivo, ao propormos discutir uma ideia de verdade e suas possíveis aproximações entre ambos os campos se justifica justamente por perceber como o próprio jornalismo, ao imputar para si certas capacidades, procura legitimar sua autoridade na e a partir da história. Pois, como vimos acima, é o jornalismo quem reconhece na História uma disciplina que em tese lhe completaria, já que constituída por problemáticas e métodos mais complexos, dos quais ele não poderia potencialmente dar conta.

Esta deliberada aproximação acaba, ao mesmo tempo, por isentar e legitimar o jornalismo enquanto instituição. Isenta, pois o coloca à margem de uma pretensa cientificidade: quando seu relato é "incompleto", é-o porque não havia como ir além ou alcançar tais resultados. Legitima-o, pois faz com que seu discurso, quando realiza trabalhos "satisfatórios", se aproxime de uma aparente 
A verdade da História no jornalismo e o lugar do jornalismo na história: apontamentos críticos de uma relação guiada pela noção de acontecimento

autoridade que só a História, com o tempo, poderia respaldar. Assim, o jornalismo se faz histórico pela forma como se apropria da disciplina, discursivamente ${ }^{14}$.

Dito isso, nos basta apenas uma observação final. Indo ao encontro da tese de Michel de Certeau (2010), devemos pensar que a atividade do historiador se faz a partir de certos procedimentos que conferem a seu ofício algumas particularidades. A escrita da história deve ser problematizada, desta forma, como uma "operação historiográfica" delimitada por seu lugar social de produção (uma profissão), dotada de procedimentos de análise (a prática de uma disciplina) e produzida a partir da construção de um texto (uma literatura). Isso faz com que situemos a história frente a uma realidade deliberadamente circunscrita, visto que o historiador está inserido nela e é somente a partir dela que pode ser efetivada sua prática.

Partindo de um lugar social determinado, o que faz o historiador, portanto, é manipular seus objetos obedecendo regras de produção específicas, procedimentos que os transformariam em história, pela escrita. A operação historiográfica, enquanto uma prática e um discurso que fala da história está também situada na história, e é por isso que necessita atribuir métodos para orientar sua apreensão da realidade. Estes métodos garantem à História o estatuto de certa instituição social, cujas regras estão estipuladas por seu lugar de fala, demandando certa carga de experiências e expectativas. Está assim, sua escrita, "submetida a imposições, ligada a privilégios, enraizada em uma particularidade. É em função deste lugar que se instauram os métodos, que se delineia uma topografia de interesses, que os documentos e as questões, que lhes serão propostas, se organizam." (CERTEAU, 2010, p. 66).

Se a história está circunscrita a este lugar de fala é porque - e isso nos soa fundamental - sua produção está em disputa, sendo constantemente "vigiada" pelos atores que a constroem e reproduzem. Esta disputa, acredita Marc Ferro

\footnotetext{
${ }^{4}$ Além disso, é importante ressaltar que a História também se apropria do jornalismo quando ela o utiliza como fonte de conhecimento histórico, por exemplo. Isso está atrelado ao próprio estatuto de "objetividade" e da pretensa "ancoragem factual" presente no discurso jornalístico. Neste sentido, o jornalismo, como uma "história do seu tempo", atuaria como um importante objeto para a construção do acontecimento histórico na contemporaneidade. Para mais informação sobre estas discussões, consultar a obra: RIBEIRO, Ana Paula Goulart. A história do seu tempo: a imprensa e a produção do sentido histórico. 1995. Dissertação (Mestrado em Comunicação) - UFRJ, Rio de Janeiro, 1995.
} 
A verdade da História no jornalismo e o lugar do jornalismo na história: apontamentos críticos de uma relação guiada pela noção de acontecimento

André Bonsanto

(1989), tem se potencializado em virtude da gradativa democratização do acesso àquilo que consideramos ser de conhecimento histórico em nossa sociedade. Cada vez mais se torna necessário, de acordo com o historiador, nos questionarmos, portanto, sobre as condições de produção destes discursos. Quais temas eles privilegiam? De que maneira os abordam? Por quem eles são produzidos? Como são re(a)presentados através do tempo? Como atuam também a partir de seus silêncios e/ou esquecimentos?

Estar atento a estas questões faz com que desloquemos o problema da verdade da História para o jornalismo numa via que não é de mão única, já que elas estão constantemente a se alimentar, de forma muitas vezes paradoxal e conflituosa. É pensar que os regimes de verdade, por serem parciais, incompletos e fragmentários, metamorfoseiam-se de acordo com as conjunturas, e que a história, - em seu sentido estrito, e não como uma disciplina - se dá pelo reflexo destas cambiantes relações de poder. Mas é justamente por lidarem com a aparente perecibilidade de suas verdades que jornalistas e historiadores fazem de suas práticas um lugar privilegiado. Sem elas, acredita Nerone (2013), as narrativas sobre o mundo jamais poderiam ser ajustadas em um processo de atualização contínua, mantendo vivas as disputas pelas versões "corretas" dos fatos. Constituindo-se pelo embate e por este ininterrupto processo de atualização é que a verdade da história se insere nojornalismo, legitimando assim sua própria autoridade. Pois, como uma instituição dotada de suas próprias normativas e intencionalidades, o jornalismo também garante seu lugar, reivindicando certo protagonismo nesta disputa.

\section{Autorizando (suas) verdades: o jornalismo, seu lugar de memória e} na história

Como "rodas de fiar" da modernidade, a tessitura midiática alterou consideravelmente a forma como nos relacionamos com o tempo, instaurando aquilo que Thompson (2014) definiu como uma "historicidade mediada". Nossa relação com a história e a memória configura-se, de forma cada vez mais evidente, por experiências simbólicas midiatizadas que nos constituem quase que "por tabela" (POLLAK, 1992). O jornalismo, institucional e historicamente 
A verdade da História no jornalismo e o lugar do jornalismo na história: apontamentos críticos de uma relação guiada pela noção de acontecimento

André Bonsanto

falando, angariou assim uma suposta legitimidade para selecionar, ordenar e enunciar verdades factuais que acabam por produzir uma ideia particular de história frente à realidade. A história passa a ser “aquilo que aparece” nas mídias, já que, em tese, esta instituição conquistou o poder de elevar fatos e acontecimento à categoria de "históricos" pela forma como os apresenta "objetivamente". (RIBEIRO, 1995).

O estatuto "histórico" produzido pelos relatos jornalísticos está respaldado, no entanto, por uma maquinaria que procura garantir certa autoridade a uma instituição que se diz capaz de proferir tais discursos. Eles se reforçam sob a ideia de que "históricos" seriam aqueles fatos dignos de reconhecimento, já que conquistaram visibilidade e foram selecionados de uma série de outros acontecimentos, sendo cristalizados como memoráveis. Com o pressuposto de que atuaria como uma espécie de "testemunha ocular" da história, o jornalismo é elevado à categoria de porta-voz oficial destes acontecimentos, não apenas por relatar tais transformações, mas também por armazená-las para a posteridade. Assim, o jornalismo registraria a história tanto pelo vivido, no cotidiano dos relatos, quanto pela "formalização de memórias" sob o viés da recordação. Com isso, auxiliaria o trabalho do historiador, que poderia consultar as páginas de uma publicação para saber o que teria se passado com uma sociedade em determinado período. (RIBEIRO, 1995; 2005).

Mas este "auxílio", na verdade, se faz de uma maneira um tanto quanto impositiva, uma vez que o protagonismo exercido pelas mídias acabou por reconfigurar a forma como a própria historiografia encara suas práticas. Pierre Nora (1988) acredita que as mídias produziram uma nova percepção sobre o sentido histórico, de tal modo que o vivido acabou por se impor como história em uma espécie de "vulcões da atualidade", repetindo-se à exaustão. A redundância intrínseca à prática noticiosa tornaria assim o acontecimento “monstruoso", alimentando uma fábrica de relatos que se querem históricos pela forma como são inscritos, cotidianamente.

Fruto também de certa dilatação temporal, esta nova percepção da história é constituída por um "presente contínuo" (DOSSE, 2001) que instaura um ritmo cada vez mais acelerado. A tirania do instante deflagraria, portanto, um 
A verdade da História no jornalismo e o lugar do jornalismo na história: apontamentos críticos de uma relação guiada pela noção de acontecimento

outro regime de historicidade, definido pelo historiador François Hartog (2014) como "presentismo", no qual a imposição de um presente hipertrofiado, valorizado pelo efêmero, transformaria até mesmo nossa relação com o passado e o futuro. Ao tornar o presente onipresente pela confecção de um "ao vivo" a ser consumido, o jornalismo e as narrativas midiáticas já produziriam seus acontecimentos como históricos, reciclando e atualizando-os constantemente.

Em um cenário em que, paradoxalmente, tudo é "presente" e tudo é "histórico", vemos também uma necessidade quase imperiosa do ato de lembrar. Já que o tempo escorre em nossas mãos como um aqui e agora contínuo, há o medo de um esquecimento irrecuperável que se reflete em uma "cultura da memória" (HUYSSEN, 2001), um desejo de tudo armazenar, de parar o tempo ou, ao menos, abrir possibilidades para que o passado e seus presentes se façam futuro.

Com base neste panorama, tornou-se praticamente lugar comum, nos estudos que relacionam o jornalismo à história, afirmar que os meios de comunicação são um dos principais agentes no processo de cristalização de memórias, lembranças e esquecimentos em nossa sociedade. As mídias, os jornais e seu jornalismo consolidam-se, conforme estes estudos, como um importante "lugar de memória" da contemporaneidade, atuando de forma incisiva na veiculação, reprodução, armazenagem e/ou ressignificação de estratos do tempo ${ }^{15}$.

Não há como negarmos, de fato, que o jornalismo procura exercer cada vez mais um considerável protagonismo frente a estes embates. Desde o clássico trabalho de Maurice Halbwachs (2004) sabemos que a memória é seletiva,

\footnotetext{
15 O termo, cunhado pelo historiador Pierre Nora (1984) para pensar a questão da história cultural na França e seus "lugares", sejam materiais ou simbólicos, que atuam no processo de cristalização e ritualização de lembranças e esquecimentos, foi apropriado por uma série de estudos na Comunicação, inclusive por nosso último trabalho. (BONSANTO, 2014a). Mesmo sem negligenciarmos a importância do conceito para pensar os usos do passado na prática jornalística, queremos agora, na esteira do trabalho de Barbosa (2016), ir um pouco além desta problematização, conforme veremos logo em seguida. Para uma breve consulta sobre alguns destes estudos, consultar as coletâneas: RIBEIRO, Ana Paula Goulart; FERREIRA, Lucia Maria Alves (orgs.). Mídia e memória: a produção de sentidos nos meios de comunicação. Rio de Janeiro: Mauad X, 2007 e RIBEIRO, Ana Paula Goulart; HERSCHMANN, Micael (orgs.). Comunicação e história: interfaces e novas abordagens. Rio de Janeiro: Mauad X: Globo Universidade, 2008.
} 
A verdade da História no jornalismo e o lugar do jornalismo na história: apontamentos críticos de uma relação guiada pela noção de acontecimento

André Bonsanto

fragmentária, por isso passível de manipulações, confrontos e enquadramentos (POLLAK, 1989). Sabemos também que, mais do que uma oposição à história, a memória é um dos elementos que a constitui, alimentando-a, mesmo que conflituosamente (RICOEUR, 2007). É por isso que a memória precisa ser enxergada em seu poder de mediação, com o que o jornalismo passa a ser visto não como um simples canal e/ou ferramenta pelo/a qual ela se expressa, mas como um dos agentes que acabam por the garantir suas potencialidades, enquanto fenômeno dotado de significações (EDY, 1999; ZELIZER, 2008).

E é justamente por ser um ator fundamental neste processo de mediação que o jornalismo precisa ser encarado a partir de uma relação muito mais complexa no que toca sua aproximação com a história. A constatação, - quase um "cliché”, segundo Edy (1999), - de que seu trabalho se daria pela confecção de um mero "rascunho" da história, dificulta a possibilidade de enxergarmos outras perspectivas nem sempre aparentes da discussão. Se deslocarmos nosso olhar às utilizações do passado não apenas na construção, mas na reconstrução dos acontecimentos no tempo, conseguiremos pensar o jornalismo como uma prática que realiza também uma "segunda escrita” deste rascunho. Escrita que nos oferece uma oportunidade para pensar como o próprio jornalismo reexamina o (seu) passado, construindo um tipo particular de história que é revelada à cena pública por sua produção noticiosa.

O jornalista pode ser encarado neste sentido como um importante "fazedor" de história da contemporaneidade, mesmo que, aparentemente, esta possa ser uma característica negligenciada pelos critérios de noticiabilidade e pelo estatuto de "atualidade" de suas práticas (BONSANTO, 2014b). Ao naturalizar a ideia de que o passado estaria fora dos limites de sua função, estes critérios obscurecem uma relação dinâmica e com caminhos muitos mais problemáticos (ZELIZER, 2008). Fato é que os jornalistas e suas empresas constroem e rememoram o passado para atender agendas específicas, não necessariamente preocupadas com um labor historiográfico. Daí a importância de se problematizar que parte do passado ou que tipo de expectativa de futuro é trazido aos embates do presente, a partir dessa reconstrução mnemônica. Além disso, as narrativas históricas construídas e simbolizadas midiaticamente potencializam uma 
A verdade da História no jornalismo e o lugar do jornalismo na história: apontamentos críticos de uma relação guiada pela noção de acontecimento

André Bonsanto

conexão emocional e afetiva entre o presente e o passado, sendo que seu trabalho nos encoraja a olhar criticamente para o modo como este passado nos chega e em quais conjunturas.

Por ser construída a partir de agendas específicas é que a escrita jornalística da/sobre a história comumente é vista como relativista, simplificadora. Uma escrita que abusa da memória e a encaixa no presente, sem maiores problematizações. (EDY, 1999) Tensionada pelo viés comemorativo da lembrança, sua produção é também impulsionada por um mercado de notícias sobre o passado, mais do que por um saber especializado. No entanto, por mais que evidentemente "presentista", este trabalho não surge, obviamente, de um nada histórico. Pelo contrário, ele se inscreve sempre sob uma memória sóciohistórica que é determinante para a compreensão de seus relatos. Assim, Antunes (2014) acredita que os acontecimentos jornalísticos necessitam do passado para constituir suas narrativas, pois estes precisam referenciar o contexto de sua emergência. Há de se distinguir o que é notícia do que é história sem negar sua historicidade. A questão a se pensar é, acima de tudo, qual a suposta relação que se dá entre elas.

Ao nos questionarmos sobre a historicidade dos relatos jornalísticos devemos levar em consideração que tanto a memória quanto a história se entrecruzam em uma temporalidade múltipla que não se limita à mera "atualidade" do acontecimento. O jornalismo, ao produzir uma ideia particular de história para a constituição de seus textos, realiza uma série de operações que, seja por analogia e/ou problematização de contextos, nos chegam como notícia inserindo-se na memória, moldando-se nela e a partir dela. O jornalismo não é, portanto, um discurso ou produto que se baseia apenas na história e suas memórias, mas um agente que, processualmente, está inserido na cultura que o constitui (KITCH, 2008).

Seus relatos são passíveis de transformação, pois inseridos no tempo. São muitas vezes "utilizados" a partir de conjunturas diversas. São conflituosos e se colocam em embate com outros agentes que se querem autorizados a proferir tais discursos. Isso porque este processo é fundamental para construir, inclusive, a própria imagem daquele que o produz, definindo fronteiras e separando as 
A verdade da História no jornalismo e o lugar do jornalismo na história: apontamentos críticos de uma relação guiada pela noção de acontecimento

André Bonsanto

instituições de acordo com suas capacidades. Dizer isso é afirmar que o jornalismo também se apropria de memórias particulares e que intenta, a partir delas, legitimar a sua própria história.

Como um processo de seleção e construção, o jornalismo modela e ordena aquilo que deve ser de reconhecimento do seu público, hierarquizando determinados fatos e acontecimentos, em detrimento de outros. Uma negociação envolvendo enquadramentos que, por um lado, são inerentes à própria produção noticiosa: o jornalismo apresenta a seu público estes embates e com base neles reconstitui aquilo que "acontece" na sociedade. Por outro lado, ele pode ser considerado como um ator fundamental dentro deste mesmo processo, já que, enquanto instituição, acaba por competir com outros atores para revelar suas "verdades", autorizando-se a se portar como um ator legítimo frente ao relato dos acontecimentos (Neiger, Meyers e Zandberg, 2011).

Inserir a memória no jornalismo é pensar, portanto, que ela não é apenas uma ferramenta ou instrumento auxiliar de seu discurso, mas que é muitas vezes constituinte do seu próprio discurso. Para legitimar a suposta ancoragem factual sobre a qual se sustenta, o jornalismo nada mais faz do que se apropriar de um passado, um passado que se faz presente pela memória, em seu poder de enunciação. Esta memória pode então ser acionada pela prática jornalística à medida que a instituição julgar necessário situar-se em contextos mais amplos, seja para produzir determina notícia, seja para "dar-se ao direito" de conduzir a história, pela forma como arranja estas lembranças. O jornalismo enquanto instituição legitima assim um papel que vai além da mera mediação e/ou ordenamento da memória. Se ele a porta e se diz autorizado a reproduzi-las, o faz não apenas para explicar aquilo que de fato "aconteceu”, mas para produzir história, sua própria história sobre os acontecimentos no tempo (NEIGER, MEYERS e ZANDBERG, 2011).

Ciente destas particularidades e das possíveis aproximações e embates que aqui buscamos pontuar, não podemos negligenciar que, ao falar de memória, estamos tratando de uma potencialidade que só está presente "no" jornalismo porque é inerente ao trabalho "do" próprio jornalismo enquanto instituição. Os jornais e seu jornalismo contam histórias, construindo notícias e relatando 
A verdade da História no jornalismo e o lugar do jornalismo na história: apontamentos críticos de uma relação guiada pela noção de acontecimento

André Bonsanto

acontecimentos, mas também contam as suas histórias. Eles fazem jornalismo, mas também falam sobre o jornalismo que praticam. E se falam é porque seus discursos de autolegitimação são fundamentais para consolidar a autoridade de uma instituição que não apenas diz produzir relatos mais "verdadeiros" do que os dos outros, mas que se sente no direito de contar estas verdadeiras histórias (Zandberg, 2010).

É importante também destacar que, quando falamos de autoridade, queremos nos referir ao que Zelizer (1992) caracteriza como uma "fonte de conhecimento codificado" que, em tese, orientaria as pessoas sobre determinados padrões de ação, estruturando os modos pelos quais elas compreendem o mundo. Ao orientar tais padrões, a autoridade criaria um espaço comum entre os atores que proferem seus discursos, mantendo-os congregados a partir de certas premissas. É a partir destas comunidades e a suposta autoridade portada por elas que os jornais e seus jornalistas trabalham para manter as suas próprias versões sobre determinados eventos públicos ${ }^{16}$.

Pela forma como vai sendo repetido e reconfigurado narrativamente aquilo que nos chega como "a história", a autoridade, em seu processo de legitimação, se daria em diferentes momentos do tempo, pois elaborada na e pela memória, de maneira sempre conflituosa. Neste ponto, Zelizer (1992) acredita que a memória e a autoridade possuem um ponto de interação que thes parece complementar. É a memória que nos faz enxergar como emergem determinados "padrões de autoridade" ao longo do tempo, mostrando-nos como diferentes grupos, com suas agendas próprias, promovem as mais diversas versões, muitas vezes competitivas, sobre os acontecimentos.

Não buscamos com isso refletir apenas sobre o processo de transmissão dos acontecimentos no tempo, mas pensar a "natureza estratégica" inerente a seu processo de construção e reconfiguração. Pensar, portanto, os modos de atuação da autoridade jornalística como algo constituinte de suas próprias

\footnotetext{
6 Zelizer (1992) é enfática em afirmar que sua noção de autoridade se torna importante não apenas para pensar sobre o efeito que esta poderia causar em seu público, mas também e principalmente para pensar sobre como isto atinge os próprios portadores destes discursos, pertencentes à comunidade em si. A autoridade é capaz de fazer com que a comunidade se sinta "autorizada" a portar-se de determinadas maneiras, "moldando" a realidade dos acontecimentos com seus próprios termos.
} 
A verdade da História no jornalismo e o lugar do jornalismo na história: apontamentos críticos de uma relação guiada pela noção de acontecimento

André Bonsanto

práticas. É a ideia da autoridade que nos possibilita enxergar as relações de poder que perpassam a legitimação das "verdades" do jornalismo. Ela está por trás da construção das notícias, "capacitando" o jornalismo e sua instituição no momento em que este se afirma como legítimo para produzir seus discursos (Zelizer, 1992).

Partindo destas premissas conseguiremos, por fim, pensar a autoridade como uma chave analítica capaz de situar o jornalismo não apenas como um "lugar de memória", mas como uma instituição que procura, acima de tudo, legitimar o seu lugar "na história" (BARBOSA, 2016). Suas narrativas, ao se apropriar dos mais diversos acontecimentos ao longo do tempo, mais do que produzirem um repositório quase que cristalizado sobre o passado, acabam, na verdade, por potencializar sua temporalidade, abrindo fendas que possuem um "desejo de futuro", um lugar privilegiado frente àquilo que se intenta reconhecer como "histórico".

Para deslocar sua análise dos lugares de memória para a história, Barbosa (2016) faz algumas críticas sobre aquilo que ela definiu como um "esgarçamento" do conceito de "lugar de memória" apropriado pelos estudos da Comunicação. A primeira diz respeito ao deslocamento do próprio conceito, oriundo do campo da história e de questões referentes ao patrimônio, para outro bastante distinto, que seria o das mídias. A "utilização indiscriminada" do conceito no campo da Comunicação fez com que, segundo a autora, se desconsiderassem as particularidades de veículos que também possuem "lugares", ou seja, que estão imersos em um ambiente histórico e social. Estas leituras seriam decorrentes de análises com uma visão não processual da história, que tratam as mídias sem problematizarem suas articulações temporais, continuidades e rupturas.

Um olhar como este, genérico e "presentista", fez com que, ainda de acordo com a autora, se deixasse de problematizar melhor a própria relação das mídias com os conceitos de memória e de história. Indo além de uma mera oposição que encara a memória como uma operação de vida, portada por grupos particulares e dotada de interesses, e a história, vista como uma prática científica e intelectual, Barbosa (2016) acredita que é preciso incluirmos na discussão a questão do testemunho, fundamental à problemática dos meios de comunicação 
A verdade da História no jornalismo e o lugar do jornalismo na história: apontamentos críticos de uma relação guiada pela noção de acontecimento

e, principalmente, à do jornalismo. Ao introduzirem o pressuposto do "eu estava lá”, as narrativas jornalísticas se inserem na memória por seu nível declaratório, baseado na confiança, já que seus relatos podem também ser atestados e/ou confrontados por outros agentes que presenciaram um mesmo acontecimento. Isso o tornaria diferente da história, por exemplo, que está relacionada ao documento, atestando a sua verdade a partir de uma ordem de viés indiciário.

Enquanto a operação historiográfica buscaria uma explicação, relacionando os acontecimentos em diversos níveis, a memória estaria mais no campo da reminiscência. É a memória que daria, portanto, a possibilidade de reconhecermos o passado. Já a história, pelo seu poder de representação, a partir dos documentos, faz com que cheguemos a ela por seus vestígios. Assim, enquanto a história estaria regida pela "epistemologia da verdade", a memória entraria neste jogo por seu "regime de crença", a partir de sua suposta fidelidade ao passado (BARBOSA, 2016) 17.

É por isso que a narrativa jornalística, em sua pretensão de veracidade, articula-se à noção de testemunho como forma de legitimar aquilo que "efetivamente se passou" em seus textos, construindo acontecimentos "reais" a partir de relatos "isentos" que pretendem ser, desde sua emergência, "uma espécie de arquivo para a história.". Isso significa afirmar que, "se pudesse ser feito algum tipo de generalização, o que os meios de comunicação fazem é produzir uma memória presumidamente válida e comum, inserindo-a na história e não na memória." (BARBOSA, 2016, p. 14). ${ }^{18}$

Como "memória presumidamente válida" o que o jornalismo tenta produzir, neste sentido, é um documento para a história. Um documento válido

\footnotetext{
17 Neste ponto, a autora faz um diálogo com a obra do historiador Roger Chartier (2009), que está preocupado em evidenciar as dimensões retóricas e narrativas da disciplina histórica. Dimensões que, de acordo com ele, "disputam" com a memória, a literatura e a ficção, por exemplo, a sua função social, mesmo sem de fato desprezá-las, visto que é no diálogo com elas, - e nas brechas que elas evidenciam -, que muitas vezes sua escrita se constitui. Para outra leitura que explora de forma interessante estas questões, consultar o trabalho de Ginzburg (2007).

${ }^{18}$ Se compactuarmos com esta perspectiva, devemos considerar, no entanto, que não é apenas pelo valor declaratório do testemunho que o jornalismo intenta se inserir na história. A partir de seu trabalho investigativo, - em especial aqueles que se pautam pela reconstrução de acontecimentos no tempo -, o jornalismo procura também trabalhar com "documentos" em seu poder indiciário de revelação. Sua prática seria condicionada, portanto, por uma relação de aparente complementaridade entre a memória e a história.
} 
A verdade da História no jornalismo e o lugar do jornalismo na história: apontamentos críticos de uma relação guiada pela noção de acontecimento

André Bonsanto

e autorizado que se pretende verdadeiro, pois baseado em relatos que "realmente aconteceram". Inserindo-se como um lugar na história, ele entra nos jogos dialéticos da lembrança e do esquecimento, nas disputas por poder e visibilidade, nas lutas por reconhecimento. São discursos que procuram ser reconhecidos de acordo com a forma que se articulam e se (re)apropriam no tempo. Se o jornalismo usa o passado, o faz sempre na tentativa de ancorar um presente válido, a saber, aquele que possa ser "aproveitado" sob perspectivas futuras, construindo uma narrativa "para permanecer e ser reutilizada [...como] arquivos da e para a história”. (BARBOSA, 2016, p. 21).

Se é, portanto, a partir da utilização seletiva da memória que o jornalismo se apropria da história, não podemos negligenciar que ele também produz rastros. É a partir deles e na tentativa de os tornar legítimos e credíveis que o jornalismo se insere na história. Rastros que só se tornam visíveis pela inscrição do acontecimento e pela forma como eles, narrativamente, se articulam no tempo. Assim, a noção de acontecimento surge para nós como um aspecto central deste percurso, em uma relação que se dá entre aquilo que o jornalismo produz enquanto instituição, entre seus discursos e práticas.

Pela forma como o jornalismo se apropria de seus acontecimentos é que a memória, a lembrança e o esquecimento vão emergir como estratégias narrativas fundamentais na tentativa de legitimar um tipo particular de história, inerente ao próprio jornalismo em seu percurso do reconhecimento. Uma verdade que se pretende, que se inscreve no tempo, se torna rastro, se ressignifica, ressurge em diferentes estratos e nas mais diversas conjunturas. Uma verdade que, pela memória, procura definir a instituição, legitimar sua autoridade e fazer dela (a sua própria) história.

\section{O acontecimento como ponto de interseção: entre jornalismo, memória e história}

Inserindo o jornalismo nestas lutas por legitimação e reconhecimento nós conseguimos definir um ponto de interseção que não apenas aproxima, mas que nos faz pensar suas práticas a partir de características comuns em sua relação com a memória e a história. Cabe agora situarmos melhor a noção de 
A verdade da História no jornalismo e o lugar do jornalismo na história: apontamentos críticos de uma relação guiada pela noção de acontecimento

André Bonsanto

"acontecimento" para que possamos, por fim, perceber como as "verdades" que se inscrevem no jornalismo são fundamentais em a um trajeto que busca definir e incrustar uma autoridade específica à instituição. Apesar de anteriormente termos situado as especificidades que envolvem ambas as disciplinas em sua relação com a verdade, é preciso ressaltar que, neste ponto, concordamos com a tese de que seria equivocado separarmos de forma estrita o acontecimento histórico do jornalístico, uma vez que eles se alimentam, por mais que conflituosamente, de premissas complementares. Com base nisso é possível afirmar que tanto o jornalismo quanto a História, trilhando caminhos de apreensão diversos, trabalham com uma realidade que é configurada narrativamente. ${ }^{19}$ Realidade que não seria exterior ao seu trabalho, mas prefigurada por um processo de mediação que se constitui pela intriga. ${ }^{20}$

Pensar a configuração da intriga pela narrativa nos possibilita desenraizar a ideia de que o trabalho do jornalismo se daria exclusivamente por uma busca objetiva pela verdade dos fatos. Desenraizar, no entanto, não significa negar sua existência, mas deslocar o problema para uma perspectiva que não nos soe tão transparente. É pela narrativa que poderemos destrinchar os meandros do discurso e perceber as possíveis estratégias que perpassam a produção noticiosa da prática jornalística. Como um lugar de mediação, a narrativa nos auxilia a pensar não apenas o contexto de produção em que se inscrevem suas histórias, mas também e, principalmente, a dinamicidade de um espaço onde se articulam e se negociam sentidos (RESENDE, 2009).

\footnotetext{
19 Para mais informações sobre estas aproximações, consultar: BERGER, Christa; TAVARES, Frederico M. B. Tipologias do acontecimento jornalístico. In: BENETTI, Marcia; FONSECA, Virginia P. da Silveira (org.) Jornalismo e acontecimento: mapeamentos críticos. Florianópolis: Insular, 2010; DIAS, André Bonsanto. Para além do rascunho: jornalistas "fazedores de história" e as rememorações do golpe de 1964, cinquenta anos depois. Revista Lumina, v.8, n. 2, p.1-17, dez. 2014b e PONTES, Felipe Simão; SILVA, Gislene. Acontecimento jornalístico e história. In: BENETTI, Marcia; FONSECA, Virginia P. da Silveira (org.) Jornalismo e acontecimento: mapeamentos críticos. Florianópolis: Insular, 2010.

${ }^{20}$ Aqui estamos dialogando com a questão da tripla mimese proposta por Ricoeur (2010), segundo a qual a condição de emergência do acontecimento se dá por um processo de mediação entre o tempo e a narrativa. Com base nesta perspectiva acreditamos que o acontecimento jornalístico, pela tessitura da intriga, se constitui entre um mundo prefigurado do autor, sua obra e a forma como ele é apreendido no ato da leitura. Assim, seria pela mimese criadora, o texto, que poderíamos extrair a inteligibilidade da configuração narrativa, na medida em que o jornalismo produz seus acontecimentos "usando" o passado em presentes bem particulares, na tentativa de antecipar (e fazer dele) futuros possíveis. É por isso que, ao analisarmos a emergência dos acontecimentos jornalísticos, devemos estar cientes das particularidades históricas sob as quais eles se apropriam, já que estas precedem o texto e as intrigas inerentes ao seu processo de configuração.
} 
A verdade da História no jornalismo e o lugar do jornalismo na história: apontamentos críticos de uma relação guiada pela noção de acontecimento

A dinamicidade inerente às estratégias narrativas desnaturaliza assim o próprio discurso de uma verdade do jornalismo enquanto instituição. Um discurso que, ao reiterar constantemente os seus valores a partir de rituais normativos, nos evidenciam brechas que se abrem em relação a práticas muitas vezes conflitantes entre si. Estes rituais, importantes para preservar a legitimidade/autoridade do campo, acabam por camuflar o processo de constituição de uma verdade que se inscreve concomitantemente no jornalismo, enquanto prática noticiosa.

Pensando desta forma, Resende (2012) acredita que é possível deslocarmos a questão da objetividade jornalística à luz de uma dimensão discursiva que problematize os modos de "re-presentar" (tornar de novo presente) os fatos e seus acontecimentos. De acordo com o autor, a representação está relacionada às "distensões de conteúdo" que uma informação sofre ao ser colocada sob as mais diversas formas narrativas. Se há distintos modos de representar um acontecimento no tempo é porque, ainda segundo Resende (2012), a confecção narrativa pode ir além de meramente relatar os "fatos do presente", em sua pretensa objetividade, para pensar um relato sobre o "presente dos fatos". A narrativa deslocaria a "forma" da informação para sua multiplicidade de fala, tornando a busca da verdade uma apreensão dos possíveis que se abrem em discurso, ou seja, uma verdade que se pretende multifacetada e diversa. ${ }^{21}$

Apesar de o autor estar problematizando um ideal pelo qual o jornalismo deveria se pautar, cabe a nós pensar que esta perspectiva insere o acontecimento em um regime de verdade que também leva em conta o seu poder de re(a)presentação. Isso significa dizer que não nos interessa apenas problematizar como estes relatos são representados em discurso, mas como se dá um processo em que eles são seguidamente reapresentados, sob

\footnotetext{
${ }^{21}$ Reconhecer isto é afirmar o potencial dialógico da constituição narrativa, de modo que devemos problematizar o "valor de ser objetivo" e não a "objetividade como valor". Uma objetividade que "não está no número de mortos ou nas manchas de sangue que evidenciam ou comprovam a guerra. Ela está na forma de enunciar; nos espaços abertos que a narrativa cria de modo a fazer com que ali surjam sujeitos; nas condições que o repórter cria para que o leitor minimamente compreenda os mistérios que se escondem por detrás do fato aparente." (RESENDE, 2012, p. 162).
} 
A verdade da História no jornalismo e o lugar do jornalismo na história: apontamentos críticos de uma relação guiada pela noção de acontecimento

perspectivas diversas e em presentes sucessivos e particulares. É pensar, assim, o processo de dilatação e ressignificação do acontecimento no tempo, um processo que se dá muitas vezes a partir de estratégias deliberadas de construção de sentido.

Inserido na história, o acontecimento jornalístico se legitimaria pela capacidade de "fazer falar" o que ele apresenta como fato, confrontando-o a partir de um caráter pluridimensional de busca da verdade, conforme afirmou Ricoeur (1968). Neste sentido, a história seria "capturada" pelo discurso jornalístico, que construiria o acontecimento ao torná-lo reconhecível em seu processo de mediação. Não há como compactuarmos, portanto, com a noção de que o jornalismo meramente reproduz aquilo que acontece na realidade, visto que sua construção implica um certo número de operações. Dizer o que "de fato aconteceu" implica reconstituir uma cena que envolve escolhas, procedimentos de seleção e hierarquias, enquadrando cenários a partir de uma intriga que na verdade é pré-construída na e pela história (MOUILLAUD, 2002).

Fatos se tornam históricos ao encadearem-se narrativamente no tempo que os estrutura enquanto acontecimento. O jornal, envolvido em seus dispositivos, trabalha como um importante operador de sentidos no qual os acontecimentos acabam por se tornar uma "sombra projetada" dos fatos que o constituem (Mouillaud, 2002). Ainda assim é importante salientar que aquilo que nos chega como informação nunca é o mero transporte de um fato como acontecimento, mas um ciclo ininterrupto de transformações que não se encerra no acontecimento em si, já que este se processa em um constante encadeamento de dilatação temporal. ${ }^{22}$

\footnotetext{
22 Concordamos neste ponto com Sodré (2009), quando o autor afirma ser o acontecimento irredutível à lógica da história. Há assim uma distinção clara entre a noção de "fato" e a de "acontecimento". Se o primeiro está relacionado a uma "experiência sensível" da realidade, funcionando como ponto de partida para a sua apreensão, o acontecimento se constituiria como a "representação social" do fato, materializando-se em forma de notícia. A notícia, portanto, é um produto inerente ao processo de produção jornalística. Um produto que precisa ser "marcado", garantir seu "valor", ser organizado e delimitado enquanto um fluxo de possibilidades narrativas historicamente circunscritas. "Analogicamente, o acontecimento representa o fenômeno factual que se singulariza - uma "aparição" - pela produção jornalística. O produto é justamente a notícia, estratégia comunicacional constituída por um discurso nunciativo, que anuncia, avisa ou notifica um público determinado sobre uma ocorrência. A notícia corresponde na escrita jornalística ao grito do mercador em praça pública. Comunicase, em "voz alta", algo a ser notado ou sinalizado como marca factual de um instante particular.
} 
A verdade da História no jornalismo e o lugar do jornalismo na história: apontamentos críticos de uma relação guiada pela noção de acontecimento

Se não podemos reproduzir a experiência de forma transparente é porque ela está inerentemente ligada a um lugar específico, a um contexto de produção. É por isso que o acontecimento, transposto em discurso, é sempre móvel, fragmentário, passível de cortes e manipulações. Ao presumir um "contrato de comunicação", o jornalismo nomeia seus discursos, ordenando-os em um possível mundo a comentar. (CHARAUDEAU, 2006) ${ }^{23}$ Seguindo esta premissa, a realidade e aquilo que se materializa em texto não podem ser tratadas como categorias antagônicas, mas sim sobrepostas. O jornalismo, além de construir os acontecimentos, os reproduz e se apropria deles, transformando-os a partir de sua dimensão de enunciação simbólica (FRANÇA, 2012). ${ }^{24}$

Como parte de um contexto que o envolve e the dota de sentido, - mas que também abre novas possibilidades e ressignifica sua própria emergência -, o acontecimento pode assim ser pensado sob uma perspectiva que transcende seu caráter construtivista. Ele não é apenas aquilo que emerge em forma de discurso, pois está inscrito na experiência, gerando inquietações, rupturas. 0 jornalismo, desta forma, faz falar, faz ver o acontecido, mas também faz-se ver. Sua articulação narrativa não é apenas texto, mas um texto inscrito em um círculo hermenêutico que demanda uma interpretação no e para o mundo. Mais do que um fato que "significa", o acontecimento é aquilo que "se torna", pois tem o poder de afetar a ordem experiencial (QUERÉ, 2005).

Atribuir este sentido ao acontecimento é dar a ele seu próprio poder de significação, de modo que se torna possível não apenas compreendê-lo, mas apreender uma realidade que se origina e se potencializa a partir dele. 0 acontecimento "faz compreender" o mundo que o cerca, pois também lhe é

\footnotetext{
Nesta comunicação, o tempo é uma instância pressuposta, o verdadeiro vetor da enunciação, que organiza a semiose manifesta." (Sodré, 2009, p. 91)

${ }^{23}$ Isso porque o acontecimento "não significa em si", ele depende de um olhar que o torne inteligível, que "decifre" a realidade na qual se encontra circunscrito. Em um relato sobre determinada guerra, por exemplo, Charaudeau (2006, p. 133) acredita que mortos serão sempre vistos como mortos "mas para que signifiquem "genocídio", "purificação étnica", "solução final", "vítimas do destino", é preciso que se insiram em discursos de inteligibilidade do mundo que apontam para sistemas de valores que caracterizam os grupos sociais.

${ }^{24}$ França (2012) não está problematizando apenas o jornalismo, mas a "mídia" em um contexto geral. Mídia como um "instrumento" ou "dispositivo" em que se criam, formatam e veiculam produtos. Neste processo de mediação, a mídia proporcionaria também um espaço de troca, de encontro e circulação, atuando como um novo tipo de sujeito que, por sinal, acabaria por configurar um discurso próprio e particular.
} 
A verdade da História no jornalismo e o lugar do jornalismo na história: apontamentos críticos de uma relação guiada pela noção de acontecimento

André Bonsanto

intrínseco um poder de revelação. Ao revelar algo, o acontecimento se configura com um caráter inaugural. Caráter que, vale ressaltar, não é necessariamente o início de um processo, mas a emergência de uma abertura que incita esclarecimentos, que potencializa questionamentos, que nos afeta e faz agir. As coisas mudam quando um novo acontecimento emerge. Ele introduz uma descontinuidade que, no entanto, só se torna reconhecível na continuidade que o constitui. Por isso é preciso que o acontecimento tenha um lugar, que seja identificado a partir de uma descrição, de um contexto. Só assim poderemos associá-lo a um passado e um futuro (QUERÉ, 2005).

Mas para que haja um passado e um futuro relativo ao acontecimento é, preciso, ainda segundo Queré (2005), que se produza este acontecimento. Eles são relativos ao presente de sua emergência, mas, ao mesmo tempo, ultrapassam seus determinantes contextuais pois potencializam, ampliam e até mesmo modificam um mundo de possíveis. Afetando espaços de experiência e horizontes de expectativa, o acontecimento, portanto, "continua a ocorrer" enquanto continuar produzindo efeitos na ordem do sentido. Ele transborda, espacial e temporalmente falando, tomando rumos e ritmos variáveis.

Neste constante "vir a ser", o acontecimento garante seu valor ideacional, discursivo, de representação. Isso porque para apreendê-lo é preciso que realizemos abstrações que não se limitam ao seu lugar de aparição. Estamos tratando de campos móveis, fragmentários, dispersos, que se confluem. Como o presente do acontecimento está sempre acontecendo, tanto o passado quanto o futuro relativo a ele também se modificam no tempo: "ele cria um passado porque surge a questão de saber o que o provocou e condicionou e cria um futuro porque há o interesse por suas potencialidades e suas consequências, ou seja, por seu significado, e porque se pretende, em maior ou menor grau, controlar sua reaparição." (QUERÉ, 2012, p. 27).

Em um fluxo temporal praticamente ininterrupto, os sentidos que emergem do acontecimento conquistam sempre novas dimensões, potencializam-se em discurso. Ele está em desenvolvimento, trilhando um percurso que abre novos passados e futuros a partir da perspectiva de um presente que é aberto, mas também problemático. Problemático, pois, - 
A verdade da História no jornalismo e o lugar do jornalismo na história: apontamentos críticos de uma relação guiada pela noção de acontecimento

André Bonsanto

enfatizamos novamente -, ele não se limita àquilo que é, em seu grau de aparição. O acontecimento continua acontecendo e se modifica de acordo com a perspectiva e o olhar que the damos, em diferentes e sucessivos presentes da enunciação ${ }^{25}$.

Transpondo esta problemática do acontecimento jornalístico, reforçamos mais uma vez uma de suas características fundamentais: o presente de seu relato é também dispersivo e não se limita ao simples "presentismo" ao qual aparentemente está condicionado. Ao "usar" o passado para garantir inteligibilidade a seus textos, o jornalismo articula uma intriga temporal que, em conjunturas diversas e em presentes particulares, dialoga com diferentes expectativas de futuro (BARBOSA, 2008; CASADEI, 2010; MATHEUS, 2010). Ao propormos inserir o jornalismo na memória e na história, levamos em consideração, portanto, que o acontecimento se entrecruza em temporalidades múltiplas que complexificam a ideia de "atualidade". ${ }^{26}$ Há uma tripla mimese encadeando seu processo de construção narrativa, pois o presente do discurso jornalístico "curto-circuita" os tempos, colocando em circulação representações diversas que dialogam e se sobrepõem (ANTUNES, 2007).

\footnotetext{
25 Um estudo clássico da historiografia pode nos ajudar neste ponto: a análise de Georges Duby sobre o "domingo de Bouvines", remoto acontecimento que emergiu em 27 de julho de 1214. A batalha travada naquele memorável domingo evidenciou, segundo o historiador, tanto a sua conclusão como um ponto de partida para um leque de novas interpretações e ressignificações, que ressoaram por séculos. Isso porque o acontecimento, como uma "espuma da história", faz emergir bolhas, grandes ou pequenas, que irrompem na superfície, estouram, provocam ondas que se propagam, deixando marcas duradouras. É somente a partir destas marcas, seus documentos, relatos e testemunhos, que o acontecimento confere existência. A questão é que, por ser constantemente dilatadas no tempo, muitas destas marcas podem perder sua amplitude, silenciar-se, chegar até nós de maneira deformada. Assim, cabe àquele que pretende apreender as potencialidades do acontecimento perceber as suas paradoxais ressonâncias, "por tudo aquilo cuja explosão provoca a ascensão desde as profundezas do não-dito, pelo que ele revela ao historiador das latências. Pelo próprio fato de ser excepcional, o acontecimento faz emergir, no fluxo de palavras que ele libera, vestígios que, se não nos detivéssemos nele, permaneceriam nas trevas, desapercebidos, os traços mais banais de que raramente se fala no cotidiano da vida e sobre os quais nunca se escreve. [É preciso portanto tentar apreender] como um acontecimento se faz e se desfaz, já que, afinal, ele só existe pelo que dele se diz, pois é fabricado por aqueles que difundem a sua notoriedade. Esbocei, pois, a história da lembrança de Bouvines, de sua deformação progressiva, pelo jogo, raramente inocente, da memória e do esquecimento." (DUBY, 1993, p. 11-12)

${ }^{26}$ A "atualidade" do acontecimento jornalístico deve ser vista aqui a partir de um premissa que dialoga com Sodré (2009) e que pensa sua emergência não tanto pela "substância do novo", mas por sua "marcação", pelo "ritmo" que articula frente a uma "renovação de possibilidades": "A novidade é uma possibilidade que se justapõe, como um palimpsesto, a uma outra, deixada em suspenso, mas capaz de alimentar a marcação temporal do lembrar e esquecer." (SODRÉ, 2009, p. 95).
} 
A verdade da História no jornalismo e o lugar do jornalismo na história: apontamentos críticos de uma relação guiada pela noção de acontecimento

Se o acontecimento jornalístico transborda em temporalidades múltiplas, engendrando uma série de relações, é porque não buscamos aqui problematizar apenas o "rascunho" da história produzido por ele, mas a sua constante re(a)presentação no tempo, uma segunda escrita que se dá pela forma como memória, lembrança e esquecimento articulam-se conflituosamente. Dito isto, frisamos também que nossa preocupação aqui se dá em pensar a produção destes discursos não apenas na forma estrita da notícia. Sua prática vai além da mera inscrição dos acontecimentos e é a partir deste ponto de inflexão que devemos colocar um parêntese final às nossas reflexões.

Estamos nos referindo aqui ao conceito de "operação midiográfica" proposto pela historiadora Sônia Maria de Meneses Silva (2011). Segundo a autora em sua tese, a escritura midiática atuaria tanto na elaboração de “acontecimentos emblemáticos" quanto na reelaboração de narrativas que perpassam categorias temporais as mais diversas, operando assim na (re)fundação de seus sentidos. Esta operação, uma escrita particular da história, se daria a partir da escritura do acontecimento na cena pública e na sua constante re-inscrição na duração.

Desta forma, o jornalismo atuaria simultaneamente como "tecedor de presentes" e um importante "urdidor de passados" da coletividade, produzindo diferentes versões sobre os acontecimentos a partir da forma como os articula e ressignifica. Situado em presentes sucessivos, o jornalismo buscaria, na evocação do passado, uma referência futura. E, na medida em que um acontecimento se torna constantemente reevocado por uma "memória histórica midiatizada", desenrolam-se jogos de adequações simbólicas nos quais se mobilizam interesses e estratégias de legitimação. Tessitura sobre o passado, o que essa escrita produz é um diálogo com o futuro, "num interminável esforço de retrospecção e projeção." (SILVA, 2011, p. 152). ${ }^{27}$

Pensando sob esta perspectiva poderemos perceber de maneira clara como o jornalismo escreve e, acima de tudo, inscreve (os seus) acontecimentos

\footnotetext{
${ }^{27}$ É importante ressaltar também que a proposta da autora dialoga com e se apropria do conceito de "operação historiográfica" de Certeau (2010), sobre o qual já discorremos. A ideia de Silva (2011), no entanto, é pensar um estatuto particular de escrita da história que se dá pela inscrição do acontecimento jornalístico. Escrita que, como acabamos de ver, parte de outros lugares e problemáticas, competindo e confluindo com o próprio trabalho do historiador.
} 
A verdade da História no jornalismo e o lugar do jornalismo na história: apontamentos críticos de uma relação guiada pela noção de acontecimento

no tempo. Pelo discurso e pela narrativa, os constrói e significa. Pela memória, os monumentaliza, transformando-os em um documento da e para a história. Pela rememoração e, numa tentativa deliberada de melhor explicar seus desdobramentos, os ressignifica, inscrevendo-os a partir de novos ciclos, versões e conjunturas. Não estamos com isso tratando apenas de notícias, mas de notícias que se tornam seus próprios rastros, transpondo seu contexto de emergência para outros sentidos e temporalidades. Notícias que também se tornam memória e que se querem história, pela forma como são apropriadas e utilizadas frente à própria instituição que as profere. ${ }^{28}$

Assim, o acontecimento não apenas se dilata e continua acontecendo, mas acaba por garantir uma "segunda vida", tornando-se um objeto de simbolização determinável, passível a novas identificações e significações. Voltamos a Queré (2012, p. 31-33) para pensar, por fim, que é pela comunicação que o acontecimento vai suscitar outros modos de apreensão, justamente porque ele pode ter sua ação controlada, seu curso atenuado, seu impacto ampliado e/ou reduzido, ao tornar-se objeto, "agentes da história que se faz." Como agentes operados simbolicamente, eles também são objetos de julgamento, um julgamento que deve ser realizado pela investigação de suas condições internas, por suas relações com outros acontecimentos, seus condicionantes e possíveis consequências.

\footnotetext{
${ }^{28}$ Apesar de partir de uma leitura diversa, a análise de Pontes (2009) também pode nos auxiliar a pensar estas aproximações e particularidades. De acordo com ele, a singularidade do jornalismo está justamente em fazer emergir do acontecimento a sua "atualidade", ou seja, a sua urgência, seu movimento. Isso significa que a unidade básica de seu trabalho não se dá necessariamente pela notícia diária, mas por aquele texto que revela possíveis, alimenta, instiga rupturas e fluxos temporais nos acontecimentos. A compreensão da história no jornalismo seria, portanto, de acordo com o autor, mais "fluida", "urgente" e "política". Assim, ainda segundo Pontes (2009, p. 166), apesar de o jornalismo se preocupar com a causa dos fatos que reporta, ele se ateria muito mais às consequências, de modo que o futuro do acontecimento é uma perspectiva aberta que se realiza como prognóstico. "A história quer localizar os pontos nevrálgicos da ruptura. O jornalismo parte da ruptura. [...] Conforme o jornalismo aprofunda a investigação, realizando novas apurações, organiza comentários, editoriais, crônicas, charges, suítes, reportagens, ele aprofunda a ruptura, o acontecimento. O jornalismo não caminha apenas para o particular. A partir do momento em que o fato se generaliza, a pertinência jornalística tem a tendência de cessar. Até o momento que um novo fato pode reabrir o acontecimento." (PONTES, 2009, p. 166). Ao realizar esse trabalho, o jornalista não sairia de sua esfera de atuação. Pelo contrário, estaria alargando sua dimensão frente às potencialidades do acontecimento, servindo inclusive como fonte de conhecimento para a sociologia e a história. Ainda assim esta seria uma prática eminentemente jornalística, com interesse particular para o jornalismo. A questão a saber é, finaliza o autor, que tipos de interesses são esses, como e quando são articulados, seja narrativamente, seja a partir de estratégias discursivas e de legitimação de sentido.
} 
Ao partilharmos desta concepção, é preciso que saibamos delimitar os acontecimentos a partir de suas séries ou ciclos, organizar temporalmente uma realidade que se faz dispersa. Os acontecimentos constituem a história, mas tomam seu lugar a partir de diferentes lugares. O que prevalece de toda esta categoria aparentemente conflitante é, segundo Queré (2012), o reconhecimento de objetos que podem ser focalizados, categorizados temporal e processualmente. Cientes disso, poderemos pensar também que é a própria instituição jornalística que realiza, deliberadamente ou não, estas delimitações. Isso porque pretende, ao domesticar suas ressonâncias, ressignificar os acontecimentos no tempo. Garantindo uma "segunda vida” no e pelo jornalismo, o acontecimento deixa de ser necessariamente notícia para disputar, com a própria história, as versões corretas de relatos que se querem autorizados e reconhecidos como tal. É por isso que, para finalizarmos com o historiador François Dosse (2013), parece caber ao jornalismo este trabalho de "dominar o impacto" dos acontecimentos, dando-lhe reabertura para um mundo que, ao mesmo tempo, possa ser passível de organização e pacificação.

\section{Considerações finais}

Ao "re-suscitar" acontecimentos no tempo podemos considerar que o jornalismo, portanto, se alimenta da história e da memória para construir, circunscrever e legitimar seus relatos. Alimenta-se, concomitantemente, dos próprios acontecimentos, em uma conflituosa relação que se dá entre lembranças e esquecimentos. Estar ciente desta antropofagia enunciativa se torna fundamental para problematizar uma relação que não diz respeito apenas à construção narrativa dos acontecimentos, mas, conforme já enfatizamos, relaciona-se diretamente com a própria autoridade "do" jornalismo enquanto instituição. Só assim poderemos inserir "no" jornalismo uma série de contextos que estão intimamente relacionados às verdades que uma instituição pretende legitimar para si. Alimentando-se dela, mas também competindo com a própria História, é que o jornalismo acaba por condicionar a (re)aparição de seus discursos. 
A verdade da História no jornalismo e o lugar do jornalismo na história: apontamentos críticos de uma relação guiada pela noção de acontecimento

Como ponto de interseção o acontecimento proporciona uma transação. Uma transação tensionada narrativa e temporalmente, delimitada por discursos que acabam por definir as fronteiras da instituição que os profere. 0 acontecimento, portanto, é afetado e afeta, pois nos abre brechas para compreender os possíveis que se abrem em discurso. Quando propomos pensar estas aproximações entre a História e o jornalismo estávamos ciente desde o início que é pelo acontecimento que elas são postas em jogo. Como um sujeito dotado de capacidades o jornalismo "enfrenta" o acontecimento, apropria-se dele, o integra à sua história, a seus projetos, experiências e expectativas. Ele nos permite descobrir algo de nós mesmos, pois são uma das fontes que constituem estes sujeitos. "A sua própria história está em causa nos acontecimentos que o afectam. Terá que os apropriar, que os incorporar na sua história e no seu projecto de vida. Terá de responder a eles e responder por eles." (Queré, 2005, p. 18).

Com base nestas asserções é que propomos deslocar a noção de acontecimento, levando em conta uma verdade circunscrita historicamente. Para além de problematizar conceitualmente a questão do acontecimento jornalístico, o que buscamos aqui foi pensar suas possíveis brechas e aproximações com a História. Com a História enquanto disciplina e/ou escrita, mas também com a história que emerge no tempo. Aquela que constitui o próprio discurso jornalístico e suas práticas, que se dá por embate e delimita a imagem que ele intenta legitimar frente às suas capacidades. Ao se alimentar da história o jornalismo potencializa uma realidade que emerge pelo próprio acontecimento, inserindo em seu discurso algumas características que lhes são particulares

Mais do que agir como um operador que realiza aquele mero registro "taquigráfico" da história, conforme nos sugeriu a própria Folha de S. Paulo na epígrafe deste trabalho, o jornalismo não se limita à construção de uma simples factualidade "presentista" dos eventos que relata. Isso porque a verdade do jornalismo está circunscrita a um horizonte de expectativas que demanda constante diálogo com a memória e a história. Desta forma, seu trabalho não se dá apenas pelo constante reexame dos discursos que profere, mas pela forma como se reapropria destes discursos, legitimando e reconfigurando sua 
A verdade da História no jornalismo e o lugar do jornalismo na história: apontamentos críticos de uma relação guiada pela noção de acontecimento

autoridade no, com e pelo tempo. A verdade da História “no” jornalismo é intrínseca à verdade "do" próprio jornalismo enquanto instituição. É nela e a partir dela que o jornalismo se faz histórico, delineando seus discursos, práticas e posicionamentos.

\section{Referências}

ANTUNES, Elton. Videntes imprevidentes: temporalidade e modos de construção do sentido de atualidade em jornais diários impressos. 2007. Tese (Doutorado em Comunicação) - Universidade Federal da Bahia, Salvador, 2007.

ANTUNES, Elton. O jornalismo é história malfeita? In: LEAL, Bruno Souza et al. (orgs.). Para entender o jornalismo. Belo Horizonte: Autêntica, 2014.

BARBOSA, Marialva. Meios de comunicação e usos do passado: temporalidade, rastros e vestígios e interfaces entre comunicação e história. In: RIBEIRO, Ana Paula Goulart; HERSCHMANN, Micael (orgs.). Comunicação e história: interfaces e novas abordagens. Rio de Janeiro: Mauad X: Globo Universidade, 2008.

BARBOSA, Marialva. Meios de comunicação: lugar de memória ou na história? Contracampo, Niterói, v. 35, n. 1, p.7-26, abril/jul. 2016.

BONSANTO, André. O presente da memória: uso do passado e as (re)construções de identidade da Folha de S. Paulo, entre o 'golpe de 1964' e a 'ditabranda'. Jundiaí: Paco Editorial, 2014a.

BONSANTO, André. Para além do rascunho: jornalistas "fazedores de história" e as rememorações do golpe de 1964, cinquenta anos depois. Revista Lumina, Juiz de Fora, v.8, n. 2, p. 1-17, dez, 2014b.

BONSANTO, André. A verdade dita é dura: "histórias da verdade" do/no jornalismo e a ditadura militar no Brasil. Tese de doutorado em Comunicação, Universidade Federal Fluminense, Niterói, 2018.

CASADEI, Eliza Bachega. Jornalismo e reconstrução do passado: os fatos históricos nas notícias de hoje. 2010. Dissertação (Mestrado em Comunicação) Universidade de São Paulo, São Paulo, 2010. 
A verdade da História no jornalismo e o lugar do jornalismo na história: apontamentos críticos de uma relação guiada pela noção de acontecimento André Bonsanto

CERTEAU, Michel de. A escrita da história. 2. ed. Rio de Janeiro: Forense Universitária, 2010.

CHARAUDEAU, Patrick. Discurso das mídias. São Paulo: Contexto, 2006.

CHARTIER, Roger. A história ou a leitura do tempo. Belo Horizonte: Autêntica, 2009.

DOSSE, François. A história a prova do tempo: da história em migalhas ao resgate do sentido. São Paulo: UNESP, 2001.

DOSSE, François. A História. Bauru: EDUSC, 2003.

DOSSE, François. Renascimento do acontecimento: um desafio para o historiador: entre Esfinge e Fênix. São Paulo: Editora Unesp, 2013.

DUBY, Georges. O domingo de Bouvines: 27 de julho de 1214. Rio de Janeiro: Paz e Terra, 1993.

EDY, Jill. Journalistic Uses of Collective Memory. Journal of Communication, v. 49, n.2, p. 71-85, 1999.

FERRO, Marc. A história vigiada. São Paulo: Martins Fontes, 1989.

FRANÇA, V. O acontecimento e a mídia. Galáxia, São Paulo, n. 24, p. 10-21, dez. 2012.

FRIAS FILHO, Otávio. [Entrevista cedida a] Alzira Alves de Abreu e Fernando Lattman-Weltman em 8 de dezembro de 1997. In: ABREU, Alzira Alves de et. al. Eles mudaram a imprensa. Rio de Janeiro: Editora FGV, 2003.

GINZBURG, Carlo. O fio e os rastros: verdadeiro, falso, fictício. São Paulo: Companhia das Letras, 2007.

HALBWACHS, Maurice. A memória coletiva. São Paulo: Centauro, 2004.

HARTOG, François. Regimes de historicidade: presentismo e experiências do tempo. Belo Horizonte: Autêntica, 2014.

HUYSSEN, Andreas. Seduzidos pela memória: arquitetura, monumentos, mídia. 2. ed. Rio de Janeiro: Aeroplano, 2001.

KITCH, Carolyn. Placing journalism inside memory - and memory studies. Memory Studies, v. 1, n. 3, p. 311-320, 2008. 
A verdade da História no jornalismo e o lugar do jornalismo na história: apontamentos críticos de uma relação guiada pela noção de acontecimento

MATHEUS, Letícia Cantarela. Comunicação, tempo, história. Tecendo o cotidiano em fios jornalísticos. 2010. Tese (Doutorado em Comunicação) - Universidade Federal Fluminense, Niterói, 2010.

MOUILLAUD, Maurice; PORTO, Sérgio Dayrell (orgs.). O jornal: da forma ao sentido. 2. ed. Brasília: Editora Universidade de Brasília, 2002.

NEIGER, Motti; MEYERS, Oren; ZANDBERG, Eyal. On media memory: editor's introduction. In: NEIGER, Motti; MEYERS, Oren; ZANDBERG, Eyal (ed.). On media memory: collective memory in a new media age. New York: Palgrave Macmillan, 2011.

NERONE, John. History, Journalism, and the Problem of Truth. In: BRENNEN, Bonnie (ed.). Assessing evidence in a postmodern world: Diederich Studies in Communication and Media, n. 3. Milwaukee: Marquette University Press, 2013.

NORA, Pierre. Les Lieux de Mémoire: La République. Présentation. Entre mémoire et histoire. Paris: Gallimard, 1984.

NORA, Pierre. O retorno do fato. In: LE GOFF, Jacques; NORA, Pierre. História: novos problemas. Rio de Janeiro, Francisco Alves, 1988.

POLLAK, Michael. Memória, Esquecimento, Silêncio. Estudos Históricos, Rio de Janeiro, v. 2, n. 3, p. 3-15, 1989.

POLLAK, Michael. Memória e identidade social. Estudos Históricos, Rio de Janeiro, v. 5, n. 10, p. 200-212, 1992.

PONTES, Felipe Simão. Teoria e história do jornalismo: desafios epistemológicos. 2009. Dissertação (Mestrado em Jornalismo) - Universidade Federal de Santa Catarina, Florianópolis, 2009.

PRINCÍPIOS editoriais. O Globo, Rio de Janeiro, 2011. Disponível em: http://memoriaglobo.globo.com/principios-editoriais/ Acesso em: 24 ago. 2019.

PROJETO editorial 1997: um panorama de mudanças na economia, na política e nas ideias. Folha de S. Paulo, São Paulo, 17 ago. 1997. Disponível em:

https://www1.folha.uol.com.br/fsp/brasil/fc170806.htm. Acesso em: 24 ago. 2019

QUÉRÉ, Louis. Entre facto e sentido: a dualidade do acontecimento. Trajecto Revista de Comunicação, Cultura e Educação, Lisboa, n. 6, p. 59-75, 2005.

QUÉRÉ, Louis. A dupla vida do acontecimento: por um realismo pragmatista. In: FRANÇA, Vera; OLIVEIRA, Luciana de (orgs.). Acontecimento: reverberações. Belo Horizonte: Autêntica, 2012. 
A verdade da História no jornalismo e o lugar do jornalismo na história: apontamentos críticos de uma relação guiada pela noção de acontecimento

RANCIĖRE, Jacques. Os nomes da história: ensaio de poética do saber. São Paulo: Editora Unesp, 2014.

RESENDE, Fernando. Jornalismo e suas Narrativas: as brechas do discurso e as possibilidades do encontro. Revista Galáxia, São Paulo, n. 18, p.31-43, dez. 2009.

RESENDE, Fernando. Falar para as massas, falar com o outro: valores e desafios do jornalismo. In: França, Vera; VAZ, Paulo. (orgs.) Comunicação midiática: instituições, valores, cultura. Belo Horizonte: Autêntica, 2012.

RIBEIRO, Ana Paula Goulart. A história do seu tempo. A imprensa e a produção do sentido histórico. 1995. Dissertação (Mestrado em Comunicação) Universidade Federal do Rio de Janeiro, Rio de Janeiro, 1995.

RIBEIRO, Ana Paula Goulart. A mídia e o lugar da história. In: HERSCHMANN, Micael; PEREIRA, Carlos Alberto Messeder. Mídia, memória e celebridades: estratégias narrativas em contextos de alta visibilidade. 2. ed. Rio de Janeiro: EPapers, 2005.

RICOEUR, Paul. História e verdade. Rio de Janeiro: Forense, 1968.

RICOEUR, Paul. A memória, a história, o esquecimento. Campinas: Unicamp, 2007.

RICOEUR, Paul. Tempo e narrativa. São Paulo: Martins Fontes, 2010. Tomo I

SCHAFF, Adam. História e verdade. 6. ed. São Paulo: Martins Fontes, 1995.

SILVA, Sônia Maria de Meneses. A operação midiográfica: a produção de acontecimentos e conhecimentos históricos através dos meios de comunicação - a Folha de São Paulo e o golpe de 1964. 2011. Tese (Doutorado em História) - Universidade Federal Fluminense, Niterói, 2011.

SODRÉ, Muniz. A narração do fato: notas para uma teoria do acontecimento. Petrópolis, Vozes, 2009.

THOMPSON, John B. A mídia e a modernidade: uma teoria social da mídia. 15. ed. Petrópolis, RJ: Vozes, 2014.

VEYNE, Paul. Como se escreve a história. Lisboa: Edições 70, 1987.

VEYNE, Paul. Acreditavam os gregos em seus mitos?: ensaio sobre a imaginação constituinte. São Paulo: Editora Unesp, 2014.

WHITE, Hayden. Meta-história: a imaginação histórica do século XIX. São Paulo: Edusp, 1992. 
A verdade da História no jornalismo e o lugar do jornalismo na história: apontamentos críticos de uma

WHITE, Hayden. Trópicos do discurso: ensaios sobre a crítica da cultura. São Paulo: Edusp, 1994.

ZANDBERG, Eyal. The right to tell the (right) story: journalism, authority and memory. Media Culture Society, v. 32, n. 1, p. 5-24, 2010.

ZELIZER, Barbie. Covering the body: the Kennedy assassination, the media, and the shaping of collective memory. Chicago: University of Chicago Press, 1992.

ZELIZER, Barbie. Why memory's work on journalism does not reflect journalism's work on memory. Memory Studies. v. 1, n. 1, p. 79-87, 2008. 